APPLYING T.G. PAGE'S SCALE FOR MEASURING BASE CRISIS RESPONSE:

A SERIES OF CRISES AT THE UNIVERSITY OF MISSOURI IN FALL 2015

\author{
A Thesis \\ presented to
}

the Faculty of the Graduate School

at the University of Missouri

In Partial Fulfillment

of the Requirements for the Degree

Master of Arts

by CONNOR VOSS

Suzette Heiman, Thesis Supervisor

JUNE 2021 
The undersigned, appointed by the dean of the Graduate School, have examined the thesis entitled

\section{APPLYING T.G. PAGE'S SCALE FOR MEASURING BASE CRISIS RESPONSE: A SERIES OF CRISES AT THE UNIVERSITY OF MISSOURI IN FALL 2015}

presented by Connor Voss, a candidate for the degree of master of arts, and hereby certify that, in their opinion, it is worthy of acceptance.

Professor Suzette Heiman

Professor Margaret Duffy

Professor Ron Kelley 


\section{ACKNOWLEDGEMENTS}

I am grateful to my outstanding committee for their continued expertise and support: Professor Suzette Heiman, my committee chair; Professor Margaret Duffy; and Professor Ron Kelley. It is through their expert guidance that this study reached its final form, and what an honor and a pleasure it has been to have learned from three of the very best journalism faculty members along the way.

I extend a special note of thanks to Professor Heiman, who has guided me since 2018 in nurturing my plans for my thesis and since my undergraduate years in deciding to pursue a graduate degree. Her thoughtful mentorship has been instrumental to my growth through this program, and I so appreciate her willingness to serve as my chair, even into the early days of her retirement. 


\section{TABLE OF CONTENTS}

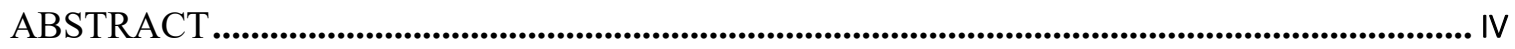

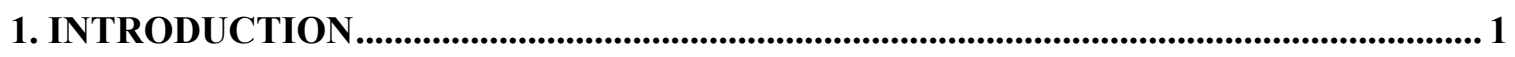

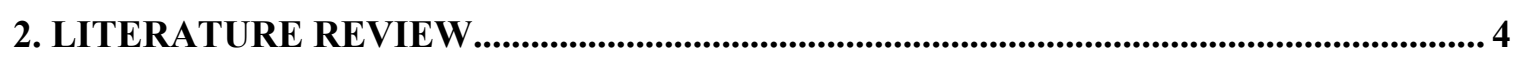

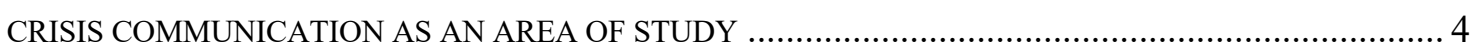

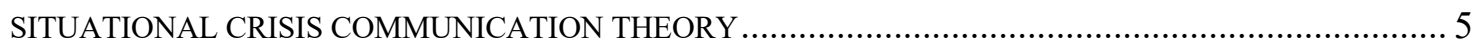

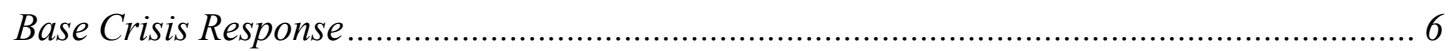

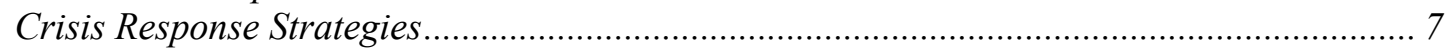

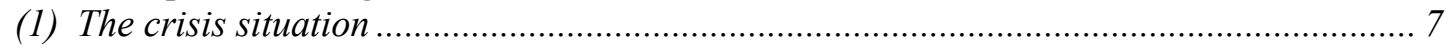

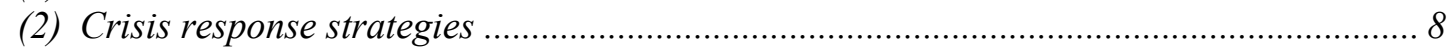

(3) System for matching the crisis situation with the crisis response strategies ................... 8

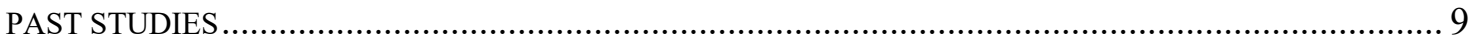

T.G. Page's Scale for Measuring Base Crisis Response .................................................... 10

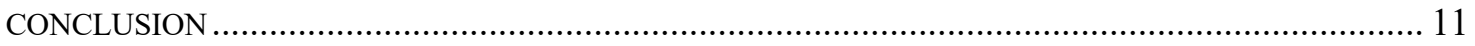

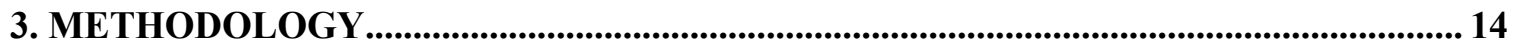

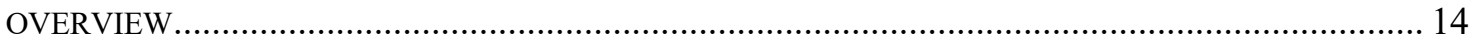

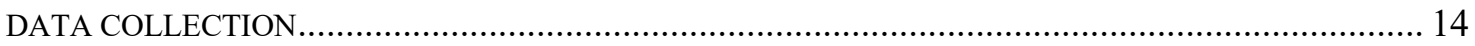

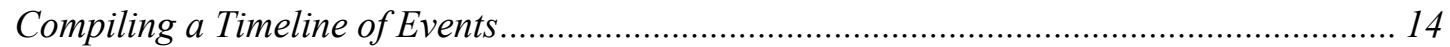

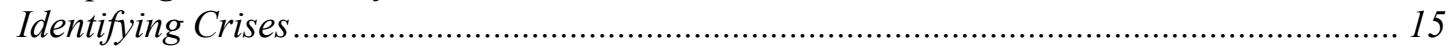

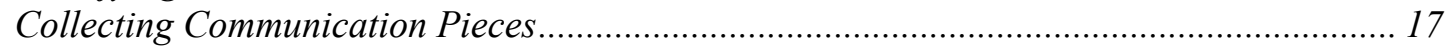

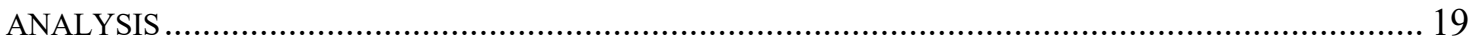

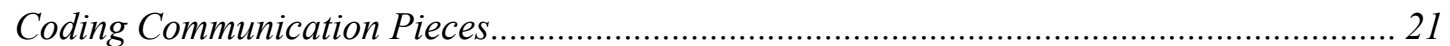

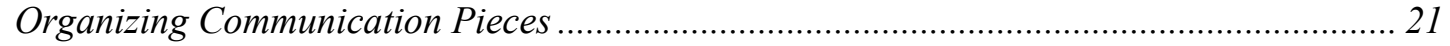

Applying Page's Scale for Measuring Base Crisis Response ............................................... 21

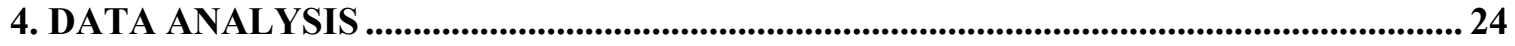

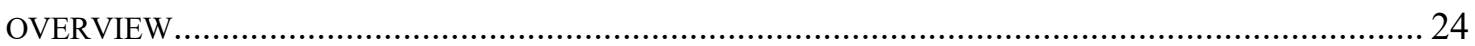

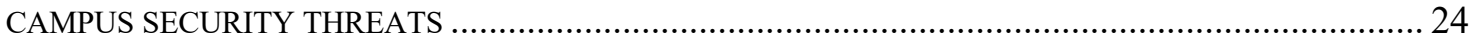

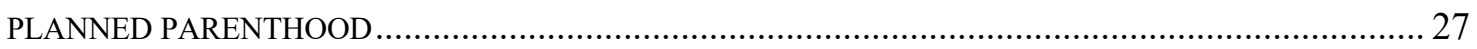

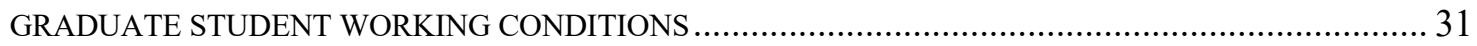

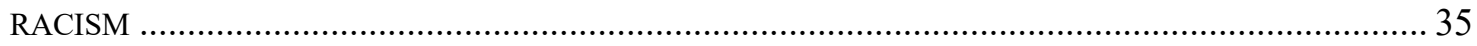

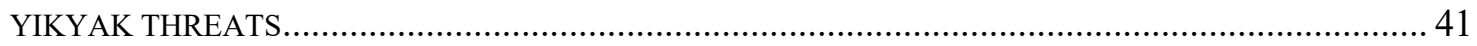

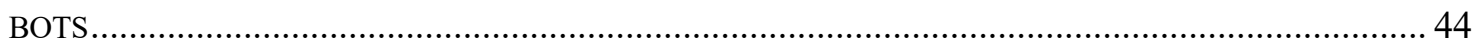

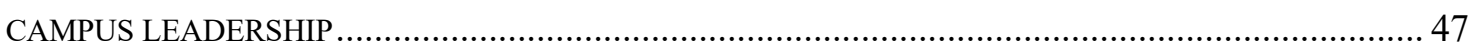

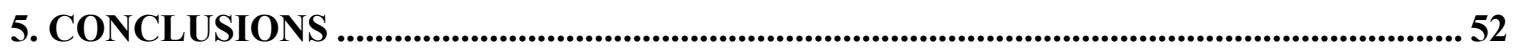

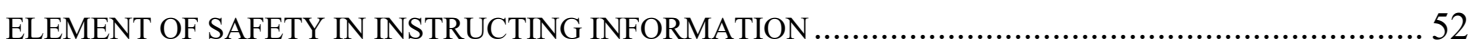

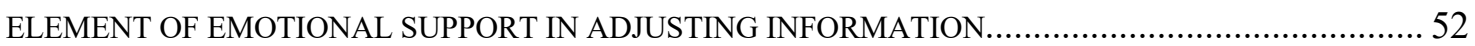

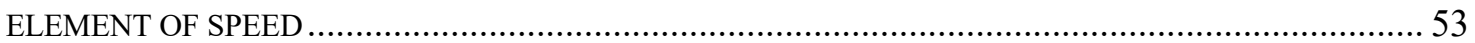

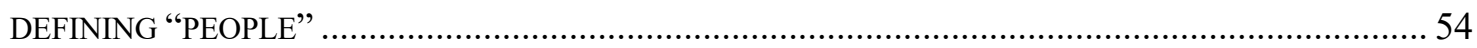

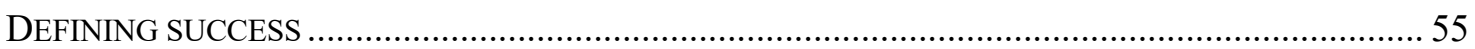

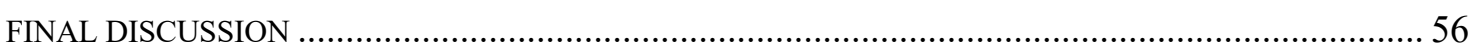

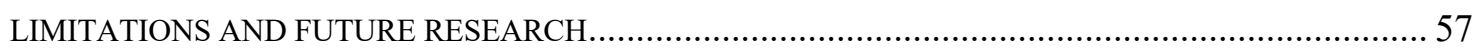

REFERENCES......................................................................................................................................5 59

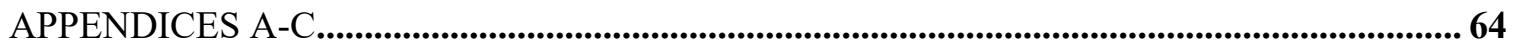




\title{
APPLYING T.G. PAGE'S SCALE FOR MEASURING BASE CRISIS RESPONSE: A SERIES OF CRISES AT THE UNIVERSITY OF MISSOURI IN FALL 2015 \\ CONNOR VOSS
}

\author{
Suzette Heiman, Thesis Supervisor
}

\begin{abstract}
This study extends theory in crisis communication by analyzing a series of crises that occurred at the University of Missouri (MU) in fall 2015 as a test case for applying T.G. Page's scale for measuring base crisis response. After applying the scale to seven crises that occurred at MU during the timeframe, several opportunities are identified for strengthening the reliability of the scale in evaluating a wider variety of crises. These include incorporating speed of base crisis response into the scale, more specifically defining the target audiences that should be considered when applying the scale, and the possibility of creating different objectives for crises in which continuity information is more applicable than safety information in the organization's base crisis response.
\end{abstract}




\section{Chapter One: Introduction}

Beginning in the fall of 2015, the University of Missouri (MU) experienced a monthslong series of complex crises on its campus. In November 2015, stories saturated nationwide news involving racial incidents on MU's campus that led students to camp in protest on the university's quadrangle, stage a hunger strike demanding the resignation of the university president, make anonymous threats to campus from the social media app YikYak, and more. Beginning earlier in the semester but receiving less media attention, the campus had begun to experience crises involving graduate student employee health insurance and the university's relationship with Planned Parenthood (Williams, 2016).

Literature in crisis communication has defined a crisis as a situation that "threatens the most fundamental goals of an organization" (Weick, 1988). The crises on MU's campus did just that, in both the short- and long term. During the fall 2015 semester, the university faced threats to its continuity of operations with the resignation of multiple leaders, students staging class walkouts, professors canceling classes during the most heated days of the campus unrest, donors revoking their support and even the football team striking in protest. Adding to the complexity, the series of crises were underscored by MU's history in matters of race relations, such as the denial of admission of Black graduate student Lucille Bluford to the Missouri School of Journalism in 1939 (State Historical Society of Missouri, 2021). Crisis communication researchers have deemed such crisis history (whether the organization has experienced similar crises in the past) as a "crisis intensifier," which can exacerbate potential reputational damage (Coombs and Holladay, 2001). 
The next year, the university continued to suffer from side effects of wounded reputation among key stakeholders. Freshman enrollment at MU fell by 22 percent in fall 2016 (Williams, 2016), and the sharp decline in enrollment led to a budget shortfall from lost tuition and subsequent cuts from the Missouri legislature, which forced MU to cut more than 400 positions and several academic programs (Williams, 2017).

Crisis communication research has suggested that the effectiveness of an organization's communication with its stakeholders during and very shortly after the crisis (deemed "base crisis response" by researchers) may predict up to $50 \%$ of the organization's post-crisis reputational outcomes (Page, 2020). W.T. Coombs, a leader in the field of crisis communication research and author of the widely applied Situational Crisis Communication Theory, has posited that most crises can be handled with successful communication during the crisis, thereby reducing the need for communication strategies to rebuild reputation following a crisis (Coombs, 2016).

Recent studies have suggested transparency, honesty, speed, and showing that the organization is in control after the crisis are of utmost importance in successful communication during a crisis (Coombs, 2015; Kim and Sung, 2014; Page, 2020; Park, 2017). Building upon this research, researcher T.G. Page developed a scale to measure an organization's base crisis response. Published in 2020, Page's study presented a series of nine objectives for researchers and practitioners to use to evaluate an organization's base crisis response (Page, 2020). At the conclusion of the study, Page calls for future research to test his scale, specifically in "real-world settings" (Page, 2020).

The purpose of this study is to do just that: This paper will extend crisis communication theory within the context of complex, real-life crises by applying Page's scale to analyze the MU's base crisis responses to the crises on its campus in fall 2015 (Page, 2020). After building a 
detailed, explanatory timeline of the crises, this study will employ qualitative textual analysis within the framework of Coombs's Situational Crisis Communication Theory to examine MU's communication with its stakeholders during and very shortly after the crises. Finally, Page's

scale will be applied to measure MU's base crisis response during each crisis. In the discussion to follow, the paper will present considerations for applying Page's scale. 


\section{Chapter Two: Literature Review}

\section{Crisis Communication as an Area of Study}

Crises have been characterized as low-probability, high-consequence occurrences that threaten the most fundamental goals of an organization (Weick, 1988). From oil spills, to recalled products, to allegations of misconduct within an organization, crises range widely in scope and severity and infinitely in context and details. On the whole, crises are frequently spurred by a violation of societal norms or expectations and can leave a negative effect on the organization's finances, reputation and stakeholders (Coombs, 2006; Coombs, 2007). An organization's stakeholders are any group that can affect or be affected by the behavior of an organization (Agle, Mitchell \& Sonnenfeld, 1999; Bryson, 2004). An organization's reputation is an aggregate evaluation that stakeholders make about how well an organization is meeting stakeholder expectations based on its past behaviors - or more simply, how an organization is perceived by its stakeholders (Wartick, 1992, Coombs, 2015).

Although "crises" are not a new phenomenon, crisis communication as a specialized practice is comparatively young. Crisis communication has been defined as "the processes whereby organizations create and exchange meanings among stakeholders regarding the risk of crisis, cause, blame, responsibility, precautionary norms, and crisis-induced changes in the organization and its relationship to stakeholders" (Seeger \& Ulmer, 2002, p. 128). In the United States, crisis communication emerged as a specialty for practitioners in the 1980s.

Theory regarding crisis communication is even newer; formal academic theory on the topic didn't emerge until the 1990s (Coombs, 2015). In 1995, W.T. Coombs drew from studies by Allen and Caillouet (1994) and Benoit (1992), which had categorized types of crisis response 
strategies. As the foundation for his theory, Coombs borrowed from psychology research, using Heider's Attribution Theory to match types of crises and types of crisis responses (Coombs, 1995). Coombs' resulting Situational Crisis Communication Theory produced a roadmap to guide organizations' crisis responses based on defining characteristics of the crisis situation (Coombs, 1995). Additional crisis communication approaches and theories have emerged that guide crisis response in other ways. To name just a couple, the "stealing thunder" approach guides organizations in response timing (Arpan \& Pompper, 2003), and Benoit’s Image Restoration Theory (1997) provides another take at classifying crises and possible responses. Since its introduction in the early days of crisis communication research, Situational Crisis Communication Theory has become one of the most widely applied theories on the topic. For example, see Sheth, et al. (2005), Jeong (2009), Claeys, et al. (2010), Sisco, et al. (2010), Kim (2017), and Barkley (2020).

\section{Situational Crisis Communication Theory}

Situational Crisis Communication Theory acknowledges three parts of the crisis response, which should occur sequentially in this order: (1) "Instructing information," the information that stakeholders will need to protect themselves during the crisis (2) "adjusting information," which helps stakeholders cope psychologically with the crisis, and (3) "crisis response strategies," also referred to as reputation management messages (Coombs, 2015; Park, 2017; Sturges, 1994). Sometimes grouped together to form the "base crisis response," instructing and adjusting information should be provided, respectively, during and shortly after the crisis has occurred. According to Coombs (2016), crisis response strategies should be employed only after the organization has fulfilled its ethical obligation to protect all potential crisis victims. A base 
crisis response, Coombs notes, is essential in all crises, while crisis response strategies may only be necessary in some crises.

\section{Base crisis response}

The concepts of instructing and adjusting information were introduced by Sturges (1994) and later accepted and incorporated by Coombs $(2007,2015)$ into Situational Crisis Communication Theory. Later literature has grouped instructing and adjusting information together to form the base crisis response (Kim \& Sung, 2014; Coombs, 2016; Park, 2017). Situational Crisis Communication Theory affirms that an organization's loyalty is to its stakeholders and any possible crisis victims, so the organization should focus first on protecting these groups through its base crisis response, instead of protecting its reputation (Coombs, 2007).

Instructing information tells potential crisis victims how to react or protect themselves physically during the crisis (Sturges, 1994; Coombs, 2007; Page, 2020). For example, this would include telling stakeholders how to avoid contaminated food during an e. coli outbreak, to change their passwords after a data security breach, or to evacuate an area where a bomb threat has been made. Coombs also identifies "continuity information," or information that addresses what the organization is doing to maintain operations during the crisis, as a type of instructing information (Coombs, 2007). Next, adjusting information helps stakeholders to cope psychologically with the crisis (Sturges, 1994; Coombs, 2007; Page, 2020). In addition to any stress caused by physical danger, the uncertainty of a crisis can create stress for stakeholders. To provide certainty and resolution, the organization should provide information and context to allow stakeholders to understand what has happened, share information for how the organization will move forward operationally after the crisis, and share any corrective actions the organization will take to protect from this risk in the future (Coombs, 2007). Above all, adjusting information 
should assure stakeholders that the organization is back in control after the crisis (Coombs, 2015; Park, 2017).

\section{Crisis response strategies}

Situational Crisis Communication Theory provides a mechanism to match crisis situations with an appropriate reputation management strategy based on the amount of responsibility attributed to the organization for the crisis (Coombs, 1995). The framework relies on three key components: (1) the crisis situation, (2) crisis response strategies, and (3) a system for matching the crisis situation and the crisis response strategies (Coombs, 1995).

\section{(1) The Crisis Situation}

Within this framework, the crisis situation is assessed based upon four elements used to determine its potential reputational threat: crisis type; severity of damage the crisis can inflict; the organization's crisis history; and the organization's relationship history with its stakeholders (Coombs, 2006). The theory classifies crisis type on two axes that Coombs found are relevant to perception of responsibility for the crisis: whether the crisis was internal (perceived to be caused by the organization) or external (perceived to have happened to the organization) and the intentionality of the event that spurred the crisis (Coombs, 1995). Coombs used these measures to identify four categories of crisis types: accidents (internal, unintentional), faux pas (external, unintentional), transgressions (internal, intentional), terrorism (external, intentional).

In this model, crisis history (whether the organization has experienced similar crises in the past) and relationship history act as "crisis intensifiers." Crisis intensifiers frequently increase potential for reputational damage, as they can heighten the perception of the organization's attribution of responsibility for the crisis, independent of crisis type (Coombs and Holladay, 2001). 


\section{(2) Crisis response strategies}

Coombs defines crisis response strategies as "the communicative resources used to protect an organization's reputation during a crisis" (Coombs, 2006). Situational Crisis Communication Theory offers three main categories of crisis response strategies (Coombs and Holladay, 1996):

- Deny, strategies that establish that there is no crisis (e.g., denial, attack the accuser)

- Diminish, strategies that lessen the attribution of crisis responsibility (e.g., excuse, justification)

- Deal, strategies that work to repair the relationship with stakeholders (e.g., compassion, regret, apology)

\section{(3) System for matching the crisis situation and the crisis response strategies}

Finally, Situational Crisis Communication Theory provides decision-making trees to match the crisis situation with the appropriate crisis response strategy to best protect and build the organization's reputation (Coombs, 1995). The matching system illustrates that as stakeholders attribute higher crisis responsibility to the organization, the crisis managers should use more accommodative crisis response strategies (Coombs and Holladay, 2002). Accommodative responses (generally in the "Deal" category) accept crisis responsibility and focus on the victims' concerns (Coombs and Holladay, 2002). Based in Heider's Attribution Theory, Situational Crisis Communication Theory posits the stronger the attributions of responsibility for the crisis, the more likely the organization will incur damage to its reputation (Claeys, Coombs, 2020). 


\section{Past Studies}

The research literature is flush with applications of Situational Crisis Communication Theory's approach to reputation management messages, but less developed in base crisis strategy (Coombs, 2016; Page, 2020). Coombs did not expand his focus in Situational Crisis Communication Theory to include base crisis response until at the latest 2007, when he seemed to accept and begin to build upon the framework of instructing and adjusting information introduced by Sturges (1994). Since then, at least four studies have specifically considered base crisis response, each driving the discourse forward.

In 2012, Sellnow, et. al, studied instructing information, specifically how learning styles, gender and group type influence the likelihood of taking action during a crisis. By testing messaging with a group of mostly white college students and a group that was predominantly Native Americans over 30, the study found that tailoring their instructing information for their audiences based on these demographics can increase the likelihood that the audience will take action (Sellnow, Sellnow, Lane \& Littlefield, 2012).

In 2014, Kim and Sung (2014) analyzed the influence of base crisis response in postcrisis reputation. Using a sample of 242 undergraduate students, the researchers manipulated the presence of base crisis responses with either matched or mismatched Situational Crisis Communication Theory crisis response strategies. They also manipulated whether the messages shared one-sided (only positive) information or two-sided (both positive and negative) information. In their study, they found that the organization's base crisis response had more influence on reputation outcomes than its reputation management messages did. Additionally, they found that sharing both positive and negative messages was more effective than sharing only positive messages in reducing the audience's perception of the organization's responsibility 
for the crisis and generating positive reputation outcomes (Kim \& Sung, 2014). This finding suggests the importance of transparency in crisis communication.

In 2017, Park studied corporate social responsibility messages and crisis responses. In a study with 301 participants, the study tested three conditions: base response, base response and reminding messages, and only reminding messages. Park found that base response and base response with reminding messages resulted in most positive reputation outcomes (Park, 2017).

\section{T.G. Page's Scale for Measuring Base Crisis Response}

The research of Sellnow, Kim and Sung, and Park set the stage for the recent work of T.G. Page. In his 2020 paper "Measuring success: Explications and measurement scales of instructing information and adjusting information," Page drew from a literature review including these previous works, interviews with 18 public relations practitioners and a study with 286 participants to put forward a scale to measure the effectiveness of instructing and adjusting information. After conducting thematic analysis of the interviews, Page concluded the key theme in instructing information should be transparency. Themes of speed, protection and honesty also surfaced as important objectives for instructing information. Explanation emerged as the key theme in adjusting information and resolution as an additional theme (Page, 2020).

With these themes as objectives, Page developed a set of statements, measured in responses of 0-10 indicating strongly disagree to strongly disagree, to measure whether instructing and adjusting information reached their objective. Although Page presents the scale as a tool for practitioners and academics to evaluate crisis messages, he emphasizes these statements should be considered from the point of view of potential crisis victims or stakeholders, which can differ from the point of view of the organization in crisis (Page, 2020). 
The first four statements in the scale assess instructing information, while (5)-(9) apply to adjusting information (Page, 2020, Table 3):

(1) The organization informed people who could be hurt.

(2) The organization helped people know to get to safety.

(3) The organization told people how to protect themselves.

(4) The organization gave information to protect people who could be harmed.

(5) The organization gave information to ease suffering after the event.

(6) The organization provided emotional support for people involved.

(7) The organization helped people move forward after the event.

(8) The organization demonstrated its commitment to helping people involved.

(9) The organization responded to people's needs after the event.

In analysis, Page found that the presence of instructing and adjusting information that met the scale's objectives of transparency, speed, protection, honesty, explanation and resolution predicted up to $50 \%$ of variation in post-crisis reputation outcomes (Page, 2020). Page's study supported previous findings of the strong influence of base crisis response in post-crisis reputation outcomes.

Page concludes his paper with a call for future research to consider his scale further to analyze its relevance, citing that his study was limited in the types of information and adjusting information it examined (Page, 2020, 8.3, 8.4.):

"This research sets the stage for a number of future studies. First and foremost, future research should confirm the validity of these measurement scales... Future research confirming these findings in experimental and real-world settings are necessary to address these limitations."

\section{Conclusion}


Crisis communication researchers note that the crisis communication literature is saturated with study of reputation management messages, at the detriment of the study of base crisis response (Coombs, 2016; Park, 2017; Page, 2020). Base crisis response has received far less study, but recent studies suggest that base crisis response may have as much or more influence in an organization's post-crisis reputation outcomes than crisis response strategies. In a 2016 paper, Coombs himself calls for more application of this area of crisis communication:

Unfortunately, there has just been too little research on instructing and adjusting information to be part of this analysis. I firmly believe that most crises can be handled by supplying instructing and adjusting information, what Situational Crisis Communication Theory terms an ethical base response. Researchers also should move beyond a preoccupation with reputation repair strategies and consider the value of instructing and adjusting information. (Coombs, 2016, p. 122)

To date, the literature studying base crisis response is narrow in the type of crises analyzed. Sellnow, et al., examined a hypothetical crisis involving contaminated frozen pot pies (2012). In another food contamination scenario, Kim and Sung tested varying versions of a hypothetical contaminated Cup-of-Soup crisis, in one case product tampering with cyanide, in another e. coli contamination (2014). Park also studied a contamination crisis, but his scenario involved water contamination caused by leaks from a waste facility (2017). Page (2020) breaks from that pattern to study a hypothetical building fire, but a building fire is not a far leap from contamination, in that both involve clear physical danger. These examples aren't representative of all crises, as many crises — from rumors to scandals to fraud— do not pose physical danger. Also notable in these examples, each crisis involved events that were inherently straightforward and easily comprehendible for stakeholders (i.e., generally, building fires and food 
contamination do not require complex explanation to understand the basic nature of the situation). Additionally, all details about the crises were clear and able to be shared immediately following the crisis, while that is not the reality that many organizations face during their times of crisis. Although these studies have provided foundational insights in base crisis response, literature in base crisis response is lacking in application to crises that are complex, ambiguous, or may threaten the organization and its stakeholders in ways other than physical safety.

A series of crises transpired at the University of Missouri (MU) in fall 2015, when MU experienced issues including race-related incidents, student protests, graduate student working conditions, MU's relationship with Planned Parenthood, bots impersonating MU students, and demanded resignation of university leaders. Some of these crises caused stakeholders to take precautionary safety measures, but, more often, the violations of societal expectations spurring the crises did not cause physical danger to stakeholders. As the crises unfolded, the details and context of what was happening often lacked clarity and were difficult to explain.

The series of crises at MU in fall 2015 provides an opportunity to apply and examine Page's scale for measuring base crisis response in light of several scenarios that differ significantly from the dangerous and relatively straightforward crises studied in existing studies. This case study will seek to build upon existing literature by analyzing base crisis response during such crises at the University of Missouri in fall 2015, examining the following questions:

RQ1: What crises occurred at MU in fall 2015?

RQ2: What instructing information did MU provide in response to each crisis?

RQ3: What adjusting information did MU provide in response to each crisis?

RQ4: Did MU's base crisis responses meet the objectives put forth in Page's scale measuring base crisis response? 


\section{Chapter Three: Methodology}

\section{Overview}

This study responds to T.G. Page's call for further consideration of his scale developed to measure base crisis response. To gather the data necessary for applying Page's scale, the researcher uses qualitative textual analysis to analyze the base crisis response that the University of Missouri employed in fall 2015 within the framework of Situational Crisis Communication Theory (SCCT). To answer RQ1, a detailed timeline of crisis events was assembled, and key crisis themes are identified. To answer RQ2 and RQ3, the university's public, external communication with stakeholders during the crisis was collected and classified as either instructing information, adjusting information or neither of the two. Finally, answering RQ4, the study employed textual analysis to analyze the instructing information and adjusting information that MU communicated, using Page's scale for determining base crisis response effectiveness. The paper concludes with a discussion of implications of the findings.

\section{Data Collection}

\section{Compiling a Timeline of Events}

A timeline of crisis events from August 1, 2015 - December 31, 2015 was compiled to provide context and framework in which to situate the communication pieces analyzed. The event timeline draws from news coverage of the campus from the Columbia Missourian, a local community newspaper chosen because of its affiliation with MU, close coverage of the university and comprehensive digital archive feature allowing for past article retrieval. This timeframe, encapsulating the full fall 2015 academic semester, was chosen to include the crisis 
timeline in totality, as well as adjusting information that may follow shortly after the crisis has ended.

To collect this data, the researcher searched the Columbia Missourian's archive feature using the following terms to generate all articles related to the university during the defined timeframe:

i. Key words: Article includes "MU" OR "Mizzou” or "University of Missouri"

ii. Date range: August 1, 2015 - December 31, 2015

\section{Identifying Crises}

After collecting all articles mentioning the university during this timeframe, the researcher used textual analysis to identify crises. For the purpose of identifying crises, Weick's definition was applied:

A situation that "threatens the most fundamental goals of an organization" (1988). Eight distinct crises emerged during the studied date range, listed in order of appearance in the timeline of events:

\section{Graduate Student Working Conditions}

MU graduate student groups are dissatisfied with conditions and benefits of their employment as graduate assistants, to include pending changes to their health insurance coverage. In response, groups hold rallies, make demands, and take steps to unionize.

\section{Campus Security Threats}

Three campus security threats occurred in course of one week: a car passing through campus that appeared to brandish a weapon, a shooting that took place near campus and a suspicious leaking container found on campus. None of the threats materialize. 


\section{Racism}

Several issues, incidents, and discussions on campus related to race occurred on the MU campus.

\section{Planned Parenthood}

In response to pressure from legislators, MU made policy changes that affected its relationship with Planned Parenthood.

\section{YikYak Threats}

During the height of the crises rooted in racism and campus leadership, two separate threats were made to people of color on the MU campus, on the anonymous social media platform YikYak.

\section{Bots}

MU discovered social media "bots" (fake social media profiles) impersonating MU students and spreading misinformation during the crisis.

\section{Campus Leadership}

Dissatisfaction and disapproval of campus leadership grew among stakeholders as other crises escalated, eventually resulting in both personnel and policy changes in campus leadership.

\section{Melissa Click ${ }^{1}$}

1 The crisis surrounding Melissa Click contributed to the state of crisis at MU during the timeframe of this study, but MU does not comment publicly on the ongoing personnel issue on its official channels during that time. Click is later dismissed from the faculty in months following the time period of this study. 
Following the resignation of MU's president and chancellor, MU Assistant Professor of Communication Melissa Click engaged in a dispute with a student journalist, where she erroneously disputed the student's First Amendment right to record the events on MU's campus. The incident was recorded, shared online and went viral.

Articles that did not relate to any crises were eliminated for further study. Examples of articles eliminated for further study were articles related to routine coverage of Mizzou's sports teams and campus events, as well as MU football head coach Gary Pinkel's retirement for health reasons. After all articles were identified that related to crises on MU's campus during that timeframe, the researcher analyzed and summarized all news coverage to assemble events chronologically into a standalone timeline. (See Appendix A.)

\section{Collecting Communication Pieces}

Next, public, external communication from the University of Missouri within this timeframe was compiled. MU communication analyzed included publicly recorded and accessible communication through the University's owned external channels. For the purpose of this study, this included the University's social media accounts, University administrators' public Twitter accounts, press releases and mass emails to the key stakeholder audiences of students, alumni and donors. (See Appendix B.)

\section{Social Media}

Included in the study were public tweets from the University of Missouri (@Mizzou), University of Missouri System (@UMSystem) and University of Missouri Board of Curators (@UMCurators) accounts. Public tweets from the following MU leaders who spoke on behalf of MU throughout the time of crisis were also included: 
MU's former chancellor R. Bowen Loftin (@BowTieger) and former Vice Chancellor for Student Affairs Cathy Scroggs (@TigerScroggs).

For this study, Twitter was examined as the primary, representative social media channel of the selected relevant social media accounts. Although the University of Missouri and the University of Missouri System also maintained Facebook and Instagram platforms during this time, the researcher found that posts were generally duplicative among all social channels. Chancellor R. Bowen Loftin and Vice Chancellor Cathy Scroggs also maintained Facebook accounts, but their account privacy settings did not allow for public study. From this time, Twitter's records are most reliable and accessible.

To obtain social media communication records for each identified account, all public social media posts on identified pages within the defined timeline were collected by using Twitter's Advanced Search feature. The researcher collected all public tweets from each account posted between August 1, 2015, and December 31, 2015, and recorded each in a spreadsheet, coding each by the account that posted it, the post date and URL to the tweet. (See Appendix B.)

\section{Press Releases}

To obtain records of press releases, the researcher searched the MU News Bureau archive within the date range of August 1, 2015, and December 31, 2015. All press releases published by MU during that time were recorded in a spreadsheet, coded with date and URL. (See Appendix B.)

\section{Emails}

Complete mass email records sent during this time to all constituent groups were not available to the researcher. The researcher was able to obtain mass email records to 
alumni and donors, as well as the Chancellor's weekly email newsletter, sent to students, faculty/staff and some alumni and donors. Thus, the emails analyzed do not represent all mass emails sent to all constituent groups during the time frame.

To compile the available email records, the researcher searched the accessible email records archive for all emails sent during the date range of August 1, 2015 December 31, 2015. This generated more than 670 total emails. To identify emails relevant to this study, the email's intended number of recipient email addresses was assessed, as well as the email subject line. Emails with recipient lists of over 122,000 were reviewed as emails sent to all emailable alumni. All Chancellor's Weekly Newsletters and Alumni Volunteer Leader Updates were reviewed. All emails that met these requirements were recorded in an Excel document, labeled with the description of the email (e.g., Chancellor's Weekly Newsletter, alumni monthly newsletter, Thanksgiving message to alumni), the send date and a URL to review the email. (See Appendix B.)

\section{Analysis}

\section{Coding Communication Pieces}

\section{Instructing Information, Adjusting Information, Both or Neither}

Next, communication was examined using textual analysis to code communication as containing instructing information, adjusting information, a combination of both, or containing neither instructing nor adjusting information. Within the spreadsheet, each piece of communication was coded I (contains instructing information), A (contains adjusting information), IA (contains both instructing information and adjusting information), or $\mathrm{N}$ (contains neither instructing information of 
adjusting information). For the purpose of this study, classification is based upon these definitions of instructing information and adjusting information presented in the literature review:

Instructing information tells potential crisis victims how to react or protect themselves physically during the crisis (Sturges, 1994; Coombs, 2007; Page, 2020).

Adjusting information helps stakeholders to cope psychologically with the crisis (Sturges, 1994; Coombs, 2007; Page, 2020).

Next, all communication pieces coded "N" (neither instructing nor adjusting information) were removed from the set of communication pieces warranting further analysis. Pieces that contained broken links (URLs that linked to webpages that were no longer active) that prevented proper understanding of the communication piece were eliminated from further study.

\section{Crisis}

In order to assess the success of MU's base crisis response specific to each crisis during this time period, it was necessary to categorize crisis communication pieces by crisis theme. Communication pieces that were coded as instructing information, adjusting information or both were next coded by one or more of the following crisis topics, as determined by the primary themes of the communication piece:

1. Graduate Student Working Conditions

2. Campus Security Threats

3. Racism

4. Planned Parenthood

5. YikYak Threats 
6. Bots

7. Campus Leadership

8. Melissa Click

\section{Melissa Click}

In coding the communication pieces, the researcher found that MU did not respond publicly to the Melissa Click crisis through any of the studied channels during the defined period. Because no instructing or adjusting information was available for analysis using Page's scale, the Melissa Click crisis was removed from the data set.

\section{Organizing Communication Pieces}

After being coded by type of base crisis response messaging and crisis theme, all coded pieces of communication from all channels studied were merged into one spreadsheet and sorted chronologically by date. Next, the timeline of events was incorporated into this chronological list. Finally, the chronological list including all communication pieces and timeline events was sorted into separate, chronological spreadsheets by theme. The resulting format - a chronological list of all crisis events and instructing and adjusting information for each crisis-primed the data for the ability to analyze using Page's scale for measuring the success of the base crisis response for each crisis that occurred on MU's campus during the timeframe. (See Appendix C.)

\section{Applying Page's Scale for Measuring Base Crisis Response}

After compiling and coding the data, the researcher analyzed whether MU's base crisis response for each crisis met the objectives put forth by T.G. Page's scale to assess base crisis response messages (Page, 2020). To do so, the researcher used textual analysis to assess the respective list of crisis events and instructing and adjusting information related to each crisis theme. Finally, for each crisis theme, the researcher rated her level of agreement with each 
objective in Page's scale, from the point of view of the stakeholder receiving MU's crisis messages.

To rate MU's base crisis response for each crisis, the researcher followed the system of rating established within Page's study. In Page's study introducing the scale he developed to measure base crisis response, study participants reviewed a hypothetical crisis and were asked to rate their level of agreement with each objective statement from $0-10$, ranging from strongly disagree to strongly agree. For each crisis theme, the researcher rated her level of agreement with each of the following statements:

Instructing information was examined against these objectives (Page, 2020, Table 3):

(1) The organization informed people who could be hurt.

(2) The organization helped people know to get to safety.

(3) The organization told people how to protect themselves.

(4) The organization gave information to protect people who could be harmed.

Adjusting information was considered against the following criteria (Page, 2020, Table 3):

(1) The organization gave information to ease suffering after the event.

(2) The organization provided emotional support for people involved.

(3) The organization helped people move forward after the event.

(4) The organization demonstrated its commitment to helping people involved.

(5) The organization responded to people's needs after the event.

To allow for clarity and standardization among the researcher's ratings for the purpose of this study, the researcher defined her levels of agreement by the following scale:

- 10 (Strongly agree) - The organization met the objective very successfully.

- 6 (Agree) - The organization met the objective successfully. 
- 2 (Disagree) - The organization attempted to meet the objective but was unsuccessful.

- 0 (Strongly disagree) - The organization made no attempt to meet the objective.

- $\mathrm{NA}-$ The objective is not applicable.

Results of this analysis are presented in Data Analysis and discussed in Conclusions. 


\section{Chapter Four: Data Analysis}

\section{Overview}

This chapter presents analysis of MU's base crisis response for each of the identified crises that occurred on its campus between August 1, 2015 - December 31, 2015, using Page's scale for measuring base crisis response. For each crisis theme, the researcher provides an overview of the crisis events; summarizes the instructing information and adjusting information MU provided; rates MU's base crisis response from the perspective of stakeholders using the nine objectives of Page's scale; and provides a brief explanation for each rating. Takeaways and implications of these ratings are discussed in Conclusions.

\section{Campus Security Threats}

\section{Crisis Overview}

Three unrelated threats of possible dangers to campus occur within a week beginning in late August 2015 that required the university to protect its students, faculty and staff from potential danger. On August 27, MU receives unconfirmed reports of a car with occupants brandishing a weapon on its campus. After searching the campus in under an hour from the initial report, the car was not located, and no one was harmed. The following day, August 28, a shooting takes place near MU's campus. Within thirty minutes, the situation is stabilized, and no members of the MU community are involved in the incident. Then, on September 3, a small leaking container is found on campus. However, after assessment, there was no danger to the public.

\section{Instructing Information}


In each instance, MU shares information through its emergency alert system, which, among multiple channels reaching its campus community, included sharing on its institutional social media profiles. Situation updates and self-protection instructions are shared as information was confirmed, with updates often only within moments of each other.

\section{Adjusting Information}

MU provided timely closure to each event with communication that the crisis threats had stabilized or resolved. MU replied to social media posts to answer questions or reassure worried stakeholders.

\section{Page's Scale Ratings}

\section{1) The organization informed people who could be hurt.}

\section{Rating: 10 (Strongly agree)}

MU successfully alerted the campus community of the threat, as soon as the information was available, through its emergency alert system.

\section{2) The organization helped people know to get to safety.}

\section{Rating: 10 (Strongly agree)}

In the messages from its emergency alert system, the university included instructions for how potential victims should protect themselves.

\section{3) The organization told people how to protect themselves.}

\section{Rating: 6 (Agree)}

In the messages from its emergency alert system, the university included instructions when necessary for how potential victims should protect themselves. MU fulfilled this objective as thoroughly as they were able with the information they had, but some stakeholders still voiced frustration on social media because the information MU initially shared was not as 
specific as they hoped. On social media, MU responded to users asking questions about information they didn't have with responses including, "We don't have all the details yet, sorry about that."

4) The organization gave information to protect people who could be harmed. Rating: 6 (Agree)

MU faced difficulty in meeting all stakeholders' demands for information about the crisis. Because of the nature of the situations, MU often needed to alert potential victims to the threats before all information was known. When information was shared that did not answer all questions, some stakeholders posted their frustration on social media that more information was not shared. For example, in the instance of shots fired near Mizzou, some users posted on Twitter criticizing MU for not specifying exactly who is most at risk by specifying where near campus shots were fired. MU followed up 20 minutes later with a location after the information was confirmed, but, for a worried potential victim, that was a long time. Although MU was not in a position to be able to feasibly meet the speed demands for information of its stakeholders, it assured stakeholders in its updates that it would provide information as soon as it was confirmed.

5) The organization gave information to ease suffering after the event.

\section{Rating: 10 (Strongly agree)}

MU provided closure to ease suffering for stakeholders by alerting through its emergency alert system as soon as the threat was confirmed to be stabilized or resolved.

6) The organization provided emotional support for people involved.

\section{Rating: NA}

This objective was not relevant, as the threats in question did not materialize to cause harm to 
any members of the campus community and resolved quickly. The crises were not severe enough to warrant emotional support for stakeholders.

7) The organization helped people move forward after the event.

\section{Rating: 10 (Strongly agree)}

MU quickly alerted the campus community once the threats were resolved, providing closure to the crisis and providing the certainty to allow stakeholders to move forward from the threat of possible harm.

\section{8) The organization demonstrated its commitment to helping people involved.}

\section{Rating: 10 (Strongly agree)}

MU demonstrated this commitment by providing prompt responses to questions or worries from members of the campus community who reached out on social media.

9) The organization responded to people's needs after the event.

\section{Rating: 10 (Strongly agree)}

In this crisis, stakeholders' needs were most related to closure and certainty. MU addressed these needs by providing definitive closure to the crisis when it was resolved and by responding to questions and reassuring concerns on social media.

\section{Planned Parenthood}

\section{Overview}

In August 2015, a Missouri state representative threatens that the legislature will withhold money from MU because a Planned Parenthood doctor has privileges at MU's University Hospital. In September, MU announces that it is ending its 26-year relationship between MU's medical and nursing schools and Planned Parenthood. Later in September, MU Health Care announces it will discontinue its "refer-and-follow" privileges on December 1. This 
means the only doctor in Columbia performing abortions loses will lose such privileges at MU's University Hospital and, by state law, that the doctor can no longer perform abortions in Columbia. In late October, the nursing school announces it will enter new agreements with Planned Parenthood to allow some students to complete rotations there.

In November, ahead of the December 1 effective date ending the refer-and-follow privileges, students deliver a petition to the MU chancellor with more than 2,500 signatures to reverse this decision. By November 24, Columbia Planned Parenthood is no longer offering abortions. On November 30, Planned Parenthood supporters hold a rally to ask MU to reconsider the decision that led to the end of abortion services in Columbia. In late December, a federal judge rules Columbia Planned Parenthood to keep its license to perform abortions.

\section{Instructing Information}

Mizzou published a press release on September 24 announcing its refer-and-follow privileges were to end December 1. On November 30, the MU chancellor released a press release statement to address the pending deadline for the discontinued refer-and-follow privileges, as well as recent challenges to an ongoing research project between MU and Planned Parenthood.

\section{Adjusting Information}

In a November 30 press release, MU's chancellor acknowledges the feelings of those negatively impacted by this decision, expresses his sympathy for those this will negatively impact, as well as his respect for those who disagree with this decision, as well as their right to peaceful protest. However, he explains that as a public university MU must follow state and federal laws. 
The statement also responds to recent challenges to a University research project at Planned Parenthood. It explains the nature of MU's academic relationship with Planned Parenthood, and that no students or researchers participate in the termination of pregnancies.

\section{Page's Scale Ratings}

1) The organization informed people who could be hurt.

\section{Rating: 6 (Agree)}

MU was clear in its information about the policy decisions made and the implications they would have.

2) The organization helped people know to get to safety.

\section{Rating: NA}

This objective does not apply to this crisis. This objective would apply to Columbia Planned Parenthood patients whose care may be affected by MU's policy changes, but such patients are stakeholders of Columbia Planned Parenthood, not MU.

3) The organization told people how to protect themselves.

\section{Rating: NA}

This objective does not apply to this crisis for the same reason detailed above.

4) The organization gave information to protect people who could be harmed.

\section{Rating: 6 (Agree)}

This objective is similar to the first objective. MU provided clear information about the policy changes and their effects.

5) The organization gave information to ease suffering after the event. 


\section{Rating: 6 (Agree)}

Similar to the objective above, MU provided clear information to allow their stakeholders to understand the policy changes.

6) The organization provided emotional support for people involved. Rating: 6 (Agree)

In the MU chancellor's statement, he acknowledges stakeholders who voiced disapproval of the decision and expressed his sympathy.

7) The organization helped people move forward after the event. Rating: 6 (Agree)

MU's clear communication allowed those who disagreed with the decision to move forward from MU's decision to end their refer-and-follow privileges. Those invested in the issue moved beyond MU's decision by finding other ways to change the status of abortion services in Columbia and were ultimately successful when a federal judge ruled to allow Columbia Planned Parenthood to keep their license to provide abortions even without refer-and-follow privileges at MU Health Care.

8) The organization demonstrated its commitment to helping people involved. Rating: 6 (Agree)

MU communication made its support clear for its students and faculty who wished to continue working with Planned Parenthood for providing women's health services.

\section{9) The organization responded to people's needs after the event.}

\section{Rating: 6 (Agree)}

Although those who disagreed with the policy decision were unhappy with it, MU allows those who disagree to be heard and seen. In his statement, the MU chancellor 
acknowledges his respect for those who disagree and mentions their plans to peacefully protest.

\section{Graduate Student Working Conditions}

\section{Overview}

On August 14, 2015, graduate students were surprised to learn that MU would end subsidized health insurance for its graduate student workers, due to an IRS interpretation of the Affordable Care Act. An email to all graduate student workers from the vice chancellor for graduate studies announced health insurance coverage would end the following day. Informed without adequate notice to secure alternative health coverage before their existing coverage expired, many graduate student workers were angered by the announcement and its timing. On August 17, following an uproar of frustration from graduate students, MU creates a task force to investigate solutions for affordable health insurance for students. The next day, the Forum on Graduate Rights publishes a letter of demands, addressing the graduate student issues beyond only health insurance. If the administration does not fulfill their list of demands by August 25, the letter states, the graduate student workers will stage a walkout on August 26.

On August 21, MU announces they have reversed the decision and will not revoke health insurance subsidies for graduate students after all. Graduate student groups reply on Twitter that, although MU had met their demand for health insurance, several items they had raised in their list of demands were still unaddressed. The next day, the Graduate Professional Council publishes a letter to the MU community, saying the administration's plans to address their grievances aren't good enough and that the "shared governance" model that the university utilizes often puts student needs on the backburner. 
As promised, graduate students hold a rally on August 26, with some professors canceling classes in support of the rally. The next day at the faculty council meeting, the administrator who handled the initial communication to graduate students that their insurance had been revoked apologizes for her mishandling of the situation. She explained that s she received guidance from professional organizations that turned out to be incorrect and referenced poor communication among the MU administration.

With frustration continuing to mount among graduate students and some sympathetic faculty, MU holds graduate student forum on September 8, where leadership responds to concerns of graduate students. By the end of the month, a graduate student group announces plans to unionize by the end of 2015 or early 2016. In mid-October, the MU chancellor guarantees graduate student health insurance subsidies will continue now and in the future. The next day, still frustrated with the conditions of their treatment as employees, graduate students hold a grade-in in Jesse Hall, in conjunction with graduate student unions across the country.

In early November, MU announces it will reverse a June decision that reduced the amount of tuition waivers to be received by some graduate assistants and full tuition waivers will be extended to all graduate student assistantships for the coming year. On November 10, the Forum on Graduate Rights rallies on Traditions Plaza, collecting signatures to form a union.

In early December, the Task Force on Graduate Student Health established in August delivers its recommendations to the administration. Addressing more of the demands that the Form on Graduate Rights, the MU Master Plan Update is released to include potential for graduate student/family housing and possibility for childcare.

\section{Instructing Information}


MU informs graduate students of the change to their health care coverage by email the day before it is set to expire. Within the day, in response to outreach from graduate students expressing frustration and confusion with the email they received letting them know their health insurance as graduate student workers would expire the next day, more information and explanation is posted on the graduate studies website and shared by the MU Chancellor. Students responded with frustration that this information was not included in the initial communication announcing the change and that this information should be emailed to students, not just posted on Twitter.

\section{Adjusting Information}

MU continues to provide further information and clarification of plans following the initial announcement. Three days after the initial email to graduate students, the MU chancellor issues a letter of apology to graduate students for the lack of appropriate notice for the change and announces that MU has created a task force to bring together ideas for the best path forward for graduate student health.

\section{Page's Scale Ratings}

(1) The organization informed people who could be hurt.

\section{Rating: 2 (Disagree)}

This crisis stemmed from inappropriate timing of instructing information. MU failed to inform the people who could be hurt soon enough.

\section{(2) The organization helped people know to get to safety.}

\section{Rating: 2 (Disagree)}

Similarly, the lack of adequate timing prevented people from having enough time to get to "safety," or to secure health insurance coverage. 
(3) The organization told people how to protect themselves.

Rating: 2 (Disagree)

In initial communications, MU did not clearly let graduate students know how they should proceed with this change in coverage. Initial communication left students frustrated and confused.

(4) The organization gave information to protect people who could be harmed.

Rating: 2 (Disagree)

Again, the lack of adequate timing of this information did not protect people who could be harmed.

(5) The organization gave information to ease suffering after the event.

Rating: 6 (Agree)

MU provided information to provide clarity and certainty, but, again, the timing of the information delivery affected the way that the information was received by the stakeholders.

(6) The organization provided emotional support for people involved.

\section{Rating: 2 (Disagree)}

The MU chancellor issued a public letter of apology for the lack of appropriate timing in informing graduate student workers of this change in their health care coverage, but the apology did not acknowledge concern for the graduate students or sincere apology for MU's lack of appropriate notice for the news.

(7) The organization helped people move forward after the event.

Rating: 2 (Disagree)

MU took steps to resolve the issues posed by the graduate student groups, but, evidenced by 
the students' continued efforts of protest and unionization, MU was unsuccessful in helping its stakeholders move past the crisis.

(8) The organization demonstrated its commitment to helping people involved.

\section{Rating: 6 (Agree)}

MU demonstrated its commitment to supporting graduate students by reversing several policy decisions in response to graduate student concerns and by creating a task force to address the issues. However, it was clear as graduate students continued with their efforts of protest and unionization that the key stakeholders did not fully accept MU's commitment.

\section{(9) The organization responded to people's needs after the event.}

\section{Rating: 6 (Agree)}

Similar to the above, MU made changes to some policies, but MU's responses did not fully meet graduate students' needs, made clear by the fact that students continued with protests and unionization.

\section{Racism}

\section{Overview}

Over the span of just over two months, MU experiences several incidents related to race on its campus. On September 12, Missouri Students Association President Payton Head shares a viral Facebook post detailing an incident he reported to have experienced near MU's campus, where men in a pickup truck yelled racial slurs at him. Head's post also details incidents that other students have experienced on campus related to their identity. The impassioned post calling on Mizzou to "wake up" is shared thousands of times on Facebook, in addition to receiving coverage in national outlets including the St. Louis Post Dispatch and Washington Post. 
On October 4, an intoxicated student disrupts a Legion of Black Collegians (LBC) Homecoming performance rehearsal, using a racial slur. LBC details the incident in a letter shared on Twitter, which included criticism of the speed of the reaction of the MU safety officer at the scene. On October 24, a swastika drawn in human feces is found on a MU residence hall bathroom wall.

As incidents continue, some students become frustrated with the way the university handles the incidents, calling responses slow and inadequate. Some students of color express they feel fearful and unsafe on campus. A group of students organizes, calling their group Concerned Student 1950 (or CS1950), in reference to the year the first Black student was admitted to MU. CS1950 begins to organize protests, holding a Racism Lives Here rally in the student center. Rally participants say they plan to protest until MU administration responds to their demands to improve the campus climate.

On October 10, CS1950 walks in protest in the Mizzou Homecoming parade and blocks the car carrying University of Missouri System President Tim Wolfe and his wife. Protestors become frustrated that Wolfe did not get out of his car to speak to the protestors and say that his car knowingly bumped one of the protestors.

On October 21, CS1950 issues a list of eight demands, requesting a response from the MU administration by October 28. Ahead of this deadline, members of CS1950 meet with UM System President Wolfe, but the students say talks did not achieve resolution. The students say President Wolfe acknowledged care for black students, but that he was not fully aware of systemic racism on system campuses and did not mention any plans for fulfilling CS1950's demands. 
On November 2, as CS1950's frustration with President Wolfe grows, graduate student Jonathan Butler begins a hunger strike, to end only when Wolfe resigns as UM System President. CS1950 begin to camp out in protest on MU's Carnahan Quad in support of Jonathan Butler, saying they will not leave until Wolfe resigns his position.

On November 6, student protestors confront President Wolfe in Kansas City when he is exiting a fundraising event. While filming the interaction, students asked Wolfe to define "systemic oppression," and Wolfe fumbles, saying: "I will give you an answer, and I'm sure it will be a wrong answer ... It's — systematic oppression is because you don't believe that you have the equal opportunity for success — " (Missourian Staff, 2015).

The video is posted on social media and goes viral.

The following day, the Black players on the Mizzou football team announce they plan to boycott all football activities until President Wolfe is removed. On November 9, the president heeded calls to resign. Following the resignation, the football team announces it is ready to play, and protestors camping on the Quad began to disassemble their camp and leave.

In the following days, Mike Middleton, first Black student admitted to MU Law School and co-founder of Legion of Black Collegians, is named interim UM System President, and the position of Vice Chancellor for Inclusion, Diversity and Equity is created and filled on an interim status. The Mizzou Alumni Association announces it will revitalize its Black Alumni Network, in response to a petition from alumni. MU forms an Office of Civil Rights and Title IX to serve its campus. At the UM System level, the UM Curators announce a plan to heal racial tensions and promote inclusivity and create the UM System Diversity, Equity and Inclusion Task Force. In the weeks following, UM System and MU leaders hold listening sessions with student groups. Instructing Information 
Five days after Payton Head's viral social media post detailing the incident he experienced on campus, MU Chancellor Loftin makes a statement referencing recent incidents, calling on the MU community to stand against incidents of bias and discrimination. Following the incident with the intoxicated student who interrupted the LBC Homecoming rehearsal, Chancellor Loftin posts a video message, saying, "It's happened again. Just last night, on Traditions Plaza. Hate and racism were alive and well at Mizzou. It's enough. Let's stop this. Let's end hatred and racism at Mizzou. We're part of the same family. You don't hate your family." On October 8, in response to the recent issues, Chancellor Loftin announces MU will develop mandatory diversity training for all faculty, staff and students.

MU's public channels studied here do not address the incidents or ongoing protests again until November 3, when Chancellor Loftin tweets, “\#MizzouHungerStrike Concerned for wellbeing of \#ConcernedStudent1950 -- a person of principle raising awareness of racism and bias." On November 5, MU posts on social media: "Racist posts and actions have no place at Mizzou."

\section{Adjusting Information}

Following the culmination of this crisis - the resignation of the UM System President and MU Chancellor-, UM System and MU channels share information about the university's plan to move forward.

Emails are sent to alumni and donors with information about what is happening. After the interim MU Chancellor and UM System Presidents are named, they go on a media tour, sharing perspective on what happened on the campus and outlines Mizzou's path forward to resolve the issues that caused the crisis. As the end of the semester nears, Mizzou channels share messages 
that look back to provide context on what happened, as well messaging that Mizzou is moving forward together.

\section{Page's Scale Ratings}

1) The organization informed people who could be hurt.

\section{Rating: 2 (Disagree)}

MU shares information addressing some of the events happening, but not all. Various stakeholders expressed frustration with the amount of time it took for MU to share information about crisis events. Some students were frustrated that MU waited five days before acknowledging Payton Head's viral Facebook post. In emails to all alumni and donors, messaging apologizes to these groups for not providing the information they felt they needed to understand the crisis as it unfolded on campus.

2) The organization helped people know to get to safety.

\section{Rating: 0 (Strongly disagree)}

MU did not address students' feelings of unsafety on campus.

3) The organization told people how to protect themselves.

Rating: 0 (Strongly disagree)

Similar to the above, MU did not address students' feelings of fear for their safety on campus.

4) The organization gave information to protect people who could be harmed.

\section{Rating: 2 (Disagree)}

In this instance, this objective is not distinguishable from Objective 1.

5) The organization gave information to ease suffering after the event. 


\section{Rating: 2 (Disagree)}

MU eventually provided contextual information, but the timing of the information provided played a factor in how it was received. In its messages to alumni and donors after the resignation events, the messages apologize for the frustration felt with the lack of information they had received to be able to understand what was happening. In the absence of MU providing such contextual information in a timely way, many stakeholders received or sought out the information from other sources.

\section{6) The organization provided emotional support for people involved.}

\section{Rating: 2 (Disagree)}

MU made efforts to do so (examples include making additional counseling resources available and holding listening sessions with students), but these efforts appear to have come too late to play a role in deescalating stakeholder emotions before the crisis continued to grow.

7) The organization helped people move forward after the event.

\section{Rating: 2 (Disagree)}

With each incident, as MU tried to resolve the crisis before it escalated to the national scale, the messages shared were not effective in helping those involved move forward, as protests continued.

8) The organization demonstrated its commitment to helping people involved.

\section{Rating: 2 (Disagree)}

The efforts that MU made to demonstrate this commitment throughout were not wellreceived by those involved, evidenced by the fact that protesting continued.

9) The organization responded to people's needs after the event. 


\section{Rating: 2 (Disagree)}

Similar to the objective above, MU's response was not satisfactory to those stakeholders, as evidenced by the continued protesting.

\section{YikYak Threats}

\section{Overview}

Shortly after 6 p.m. on November 10,2015, threatening posts appear on the anonymous social media platform, YikYak: "Some of you are alright. Don't come to campus tomorrow. I'm going to stand my ground tomorrow and shoot every black person I see.”

On social media, students advise each other to remain indoors. Many students stay in their campus housing, and some students leave campus. Army ROTC is instructed to dress in plain clothes the next day. Adding to the fear and confusion on campus, MSA President Payton Head erroneously posts on Facebook that the Ku Klux Klan was "confirmed" to be in Columbia, later retracting his post.

At 1:50 a.m. the next morning, the suspect, a student at another Missouri college, who posted the threat is arrested and found to have been located across the state, never near the MU campus.

\section{Instructing Information}

MU shares information about the situation through its emergency alert system, as well as through personal social media accounts of campus leaders. At times, information seems to conflict: At 7:36 PM, the MU chancellor posts on his personal social media that "MUPD is aware of social media threats and has increased security. Call 911 immediately if you need help." At 8:22 PM, MU posts on social media that "the only Mizzou emergency Twitter handle is @MUalert. We're aware of imposter accounts. Please report them to Twitter.” At 8:43 PM, 
Mizzou posts “Please continue to monitor@MUAlert and mualert.missouri.edu. We will update in emergency.” At 11:23 PM, Mizzou posts “In an actual emergency, @MUalert and alert systems would be activated immediately. Please don't spread rumors."

At 6:07 AM,@MUAlert breaks the news on social media that the suspect who made the threats was apprehended. The MU Chancellor is first to share the news on his personal account. Within moments later, the Mizzou social media account follows, then Vice Chancellor for Student Affairs Cathy Scroggs shares the news.

\section{Adjusting Information}

Throughout the morning of November 11, Mizzou continues to post additional updates and information. In the afternoon, Mizzou shares messaging expressing that it is listening to its community and that more counseling resources are available. Also that afternoon, MU shares a statement that acknowledges the victims and how the university will move forward.

\section{Page's Scale Ratings}

1) The organization informed people who could be hurt.

\section{Rating: 2 (Disagree)}

While the YikYak threat circulated rapidly among students, MU did not address it directly in its messaging until the next morning. Until the suspect was apprehended, Mizzou's messaging emphasized there was no emergency and not to spread rumors. Comments from students in response to these messages continued to accuse Mizzou of taking the threat lightly.

2) The organization helped people know to get to safety.

\section{Rating: 2 (Disagree)}

MU's channels continually emphasized that the situation was not an active emergency but 
did not communicate clearly and definitively that students were safe or actively dispel the circulating rumors. In the absence of assurance from MU of students' safety, students filled this void with their own information, much of which proved to be unsubstantiated rumors. Students advised each other to remain indoors that evening.

3) The organization told people how to protect themselves.

\section{Rating: 2 (Disagree)}

Interpreted in this crisis, this objective is not distinguishable from the objective above.

\section{4) The organization gave information to protect people who could be harmed.}

\section{Rating: 2 (Disagree)}

Students spoke out wanting to know more information, but MU did not have any additional information to share during that time. In the absence of confirmed information to share, MU may have helped contain the fear and misinformation spreading among students by proactively addressing that the appropriate authorities are investigating the threat, that MU is taking the threat seriously and that MU will share updates as soon as information is confirmed by MUPD.

5) The organization gave information to ease suffering after the event. Rating: 6 (Agree)

MU quickly provided information once the suspect was apprehended and that the threat was dissolved.

\section{6) The organization provided emotional support for people involved.}

\section{Rating: 6 (Agree)}

The day following the threat, MU shared messaging on its channels that more counseling resources were available for students. 


\section{7) The organization helped people move forward after the event.}

\section{Rating: 6. (Agree)}

Mizzou continued to share information about the suspect's arrest, helping to provide closure to the threat and allowing people to move forward from their fear and uncertainty. In its statement from leadership in the afternoon, MU used language describing moving forward.

\section{8) The organization demonstrated its commitment to helping people involved.}

\section{Rating: 2 (Disagree)}

In its statement following the suspect's arrest, Mizzou stated its commitment to helping those involved. However, given the overall crisis situation and diminished trust among stakeholders, the message was not accepted by all stakeholders.

9) The organization responded to people's needs after the event. Rating: 6 (Agree) MU's statement details the steps they will take to respond to students' needs, including increased counseling resources and plans for campus events to facilitate learning and discussion.

\section{Bots}

\section{Overview}

During the height of racial protests on MU's campus in mid-November, the university learns that social media bots of unknown sources are spreading misinformation by impersonating MU students and tweeting that recent terrorist attacks in France should not be receiving more media attention than the protests on MU's campus. Tweets from these bots are going viral, being shared by users who erroneously believe the bots are accounts of real MU students. At the time of this crisis, in 2015 - notably prior to the 2016 US presidential election, when the overall 
awareness of bots rose - the general public is not aware of the reality of bots, and MU is not certain of the sources of the bots.

\section{Instructing Information}

Over the course of several days, MU continues to share messaging through its channels that the tweets stakeholders may be seeing purporting to be Mizzou students are imposter accounts. MU reiterates this message nearly daily throughout this time and includes instructions in messaging for users to report such tweets to Twitter.

\section{Adjusting Information}

MU did not provide any adjusting information.

\section{Page's Scale Ratings}

\section{1) The organization informed people who could be hurt.}

\section{Rating: 2 (Disagree)}

MU directly and continually continued to share messaging through its channels about imposter accounts posing as MU students and denying that these accounts were related to MU. However, at the time this occurred, the public's understanding and awareness of bots was low, so many of the stakeholders did not believe MU when they said this. Trust in MU was also low as crises continued to escalate on the campus.

To achieve success in informing people, the audience must both receive and accept the information. For stakeholders to accept this information, more in-depth education around this message would have been required to ensure stakeholders understood and believed the message. However, unfortunately, this crisis occurred as other crises that posed a higher risk to the institution reached a head, so MU's channels did not have the bandwidth to dedicate to giving this information the saturation it needed to be effective. 


\section{2) The organization helped people know to get to safety.}

\section{Rating: 2 (Disagree)}

This objective must be interpreted abstractly to be applicable to this crisis. In this crisis, "safety" for stakeholders could be interpreted as correctly identifying a bot tweet, instead of being deceived by misinformation. In MU's messages addressing imposter tweets, MU did not commit the bandwidth to thoroughly explaining which tweets were imposters or how to identify an imposter. MU did include in its messaging for users to report such tweets to Twitter, but it did not detail how to identify them.

\section{3) The organization told people how to protect themselves.}

\section{Rating: 2 (Disagree)}

If interpreting this objective abstractly to apply in this case, protecting oneself may mean protection from disinformation. In this circumstance, objectives 3 and 4 are indistinguishable.

\section{4) The organization gave information to protect people who could be harmed.}

\section{Rating: 2 (Disagree)}

The wording of this objective does apply in a literal sense, but its implications are in the same vein as the three objectives above.

\section{5) The organization gave information to ease suffering after the event.}

\section{Rating: 0 (Strongly disagree)}

MU did not follow up to provide closure to this crisis during the timeframe studied. Due to the timing of this crisis coinciding other crises, MU had higher stakes crises that took priority for receiving bandwidth in their channels.

6) The organization provided emotional support for people involved. 


\section{Rating: 0 (Strongly disagree)}

Similar to above, MU's channels did not have the bandwidth to dedicate to providing emotional support for this crisis. Their channels were focused on providing emotional support for those involved in higher stakes crises occurring simultaneously.

\section{7) The organization helped people move forward after the event.}

\section{Rating: 0 (Strongly disagree)}

If this had been the only crisis occurring at the time, MU could have dedicated the necessary airwaves to educating their stakeholders on the nature of the crisis and continuing to clear the confusion to see that MU was not in fact at fault.

\section{8) The organization demonstrated its commitment to helping people involved.}

\section{Rating: 0 (Strongly disagree)}

In this instance, helping the people involved would look like helping them to understand the true nature of the crisis.

\section{9) The organization responded to people's needs after the event.}

\section{Rating: 0. (Strongly disagree)}

In this crisis, people's needs would include education to understand what was happening and responding to their allegations and questions.

\section{Campus Leadership}

\section{Overview}

Dissatisfaction and frustration with MU campus and UM System leadership builds as crisis after crisis mounts at MU. In mid-September 2015, MU faculty begins to publicly voice concerns about MU leadership's decisions, specifically about graduate student issues and MU's relationship with Planned Parenthood. Faculty expressed frustration about a lack of 
communication from the administration about the issues and a lack of input sought from faculty on those decisions. Frustration with campus leadership among faculty, students and other stakeholders continued to mount as crises escalated throughout the semester.

The dissatisfaction culminated in the resignation of both the University of Missouri System President Tim Wolfe and the MU Chancellor R. Bowen Loftin on November 9, 2015. Days before the resignations, Missouri lawmakers of both parties called for President Wolfe to step down, and the MU Faculty Council expresses deep concerns with the university's leadership. In an unprecedented event on the day of the resignation, nine deans signed a letter calling for Chancellor Loftin's dismissal, citing failed leadership examples of graduate student health insurance, elimination of the Vice Chancellor for Health Science position, removal of the medical school dean and "creating a toxic environment through threat, fear and intimidation." An interim system president and chancellor are named within two days of the resignations.

\section{Instructing Information}

MU's instructing information related to this crisis begins with the turnover in campus leadership. When campus leaders resign, MU publicizes the news by press conference, press release and announcements via email and social media.

\section{Adjusting Information}

In their transitions, the resigning leaders publicly express their confidence in the new leaders to follow. The new leaders reach out to student and alumni stakeholder groups via email letters, as well as participate in a series of media interviews where they share their vision for the university moving forward.

\section{Page's Scale Ratings}


1) The organization informed people who could be hurt.

Rating: 6 (Agree)

This objective doesn't translate perfectly to this crisis. However, MU successfully reached out to stakeholder groups to share the news of the leadership transition.

2) The organization helped people know to get to safety.

\section{Rating: NA}

This objective does not apply.

3) The organization told people how to protect themselves.

\section{Rating: NA}

This objective does not apply.

4) The organization gave information to protect people who could be harmed.

Rating: 6 (Agree)

Similar to above, the wording of this objective doesn't apply fully to this crisis. However,

MU shared appropriate information about the leadership transitions.

5) The organization gave information to ease suffering after the event.

\section{Rating: 6}

MU continued to provide updates about the transition and introductions to new leaders and their plans for the future, which helped ease the suffering caused by uncertainty.

6) The organization provided emotional support for people involved.

\section{Rating: NA}

This objective does not apply.

7) The organization helped people move forward after the event. 


\section{Rating: 6 (Agree)}

MU continued to share the new leadership's plans for how the university would move forward. After the leadership transition, messaging focused on looking forward.

\section{8) The organization demonstrated its commitment to helping people involved.}

\section{Rating: NA}

This objective does not apply.

9) The organization responded to people's needs after the event.

\section{Rating: 6 (Agree)}

Interpreting this objective abstractly, the psychological needs that stakeholders would likely have after such a transition in leadership would be regaining trust in leadership and resolving the uncertainty caused by the transition. To respond to these needs, the new MU leaders dedicated time to a media tour to allow stakeholders to get to know them and their plans for leading MU forward.

\section{Melissa Click}

Note: This overview is provided for context to allow fuller understanding the case study, but because MUdoes not comment on the incident on its official public channels during the timeframe of this study and the crisis does not resolve within the scope of this study, researcher did not apply Page's scale to analyze this crisis theme.

\section{Overview}

During celebrations on Carnahan Quad after Wolfe's resignation, communications professor Melissa Click asks for "muscle" to remove journalist Mark Schierbecker from a circle formed by protestors, declaring it a safe space where media is barred. Assistant director for Greek Life Janna Basler confronts student photojournalist on assignment for ESPN Tim Tai, also 
urging him to leave. Tai stands his ground, explaining that the Quad where the group is gathered is a public space and the First Amendment protects the rights of the group and the journalists to be there. The interactions are captured on camera and go viral online.

The day following the incident, Click resigned her courtesy appointment with the School of Journalism. Within two days, Title IX complaints are filed against Janna Basler and Melissa Click by former Journalism School associate dean Brian Brooks, and Basler is put on leave. In December, Janna Basler is reinstated at the Office of Greek Life. Outside of the scope of this study, Click was fired from the MU faculty in February 2016. 


\section{Chapter Five: Conclusions}

In applying Page's scale to measure MU's base crisis response for the identified crises that occurred on its campus during the timeframe of August 1, 2015 to December 1, 2015, the following considerations emerged about the scale and base crisis response within the framework of Situational Crisis Communication Theory:

\section{Element of Safety in Instructing Information}

When examining MU's base crisis response for the Campus Leadership, Planned Parenthood and Racism crises, two of the scale's objectives for instructing information did not apply in the circumstances: "The organization informed people who could be hurt" and "The organization helped people know to get to safety." Both objectives are related to safety of potential victims as an element of instructing information. In these three crises, physical safety of stakeholders was

not a concern. However, these objectives were applicable and important elements of instructing information in other crises studied where stakeholders face potential danger as a victim of the crisis, including the Campus Security Threats and YikYak Threats crises. Page correctly identified this concern as a potential limitation in his original study:

In addition, this study focused on the psychological coping aspect of adjusting information and the safety information aspect of instructing information. This focus excluded other types of instructing information (continuity information) and adjusting information. As a result, these measures may not be adequate to assess these other types of instructing information and adjusting information. (Page, 2020, 8.4)

\section{Element of Emotional Support in Adjusting Information}


Objective 2 of Adjusting Information, "The organization provided emotional support for people involved," could not be applied in the Campus Leadership and Campus Security Threats crises. In the instance of the Campus Security Threats crisis, the incidents were minorthankfully, only threats of possible harm that were resolved within a few hours or less. In this instance, emphasizing emotional support after the fact for such threats could have prevented stakeholders from moving forward by amplifying the crisis beyond its appropriate scope. As related to Campus Leadership, this element does not translate to a relevant tool to help stakeholders cope psychologically with the crisis. Instead, the objectives of adjusting information that demonstrate to stakeholders that the organization is back in control after the crisis ("The organization gave information to ease suffering after the event," "The organization helped people move forward after the event") were most applicable. Page also proactively identified this limitation in his original study, as cited in the quote above.

\section{Element of Speed}

Speed as an element of a successful base crisis response came up as a sub-theme in the interviews that Page conducted to base his scale upon. However, timeliness is not directly addressed in the scale's objectives. It could be assumed that the element of speed is implied in many of the objectives: for example, if an organization successfully helped potential victims know to get to safety, they must have provided this information in time for victims to act upon it. However, for some crises, the water is murkier.

In the example of Graduate Student Working Conditions, MU did inform the student employees that their health insurance coverage would change, but they only provided this information the day before the coverage was set to expire, even though this information was known to administrators before this date. Technically, MU informed these stakeholders, but the 
timing of the notice exacerbated the crisis. The issue of timing of crisis response bubbled up in the Racism crisis as well. After Missouri Students Association President Payton Head's viral Facebook post detailing an incident of racism he experienced on campus, students were frustrated by the fact that it took MU five days to respond publicly to the incident.

These examples also highlight the real-time challenges of the expectation of response speed in instances where all facts about the crises are not immediately known. Often, stakeholders' expectations of the information MU should have or know about a crisis did not align with the information that was actually known at the time. As illustrated in the Racism crisis, stakeholders expected MU to respond swiftly and immediately to each incident. At times, frustration mounted as stakeholders expected a response from MU before all the facts were available to have a full understanding of the situation. Some stakeholders even expected MU could have been able to prevent the incidents from occurring in the first place yet, when there was no way MU could have anticipated that such events would occur.

\section{Defining "People"}

Each objective uses the word "people" to categorize the target audience (i.e., "The organization informed people who could be hurt"). However, in many of the crises studied here, MU's responsibilities were not the same for all "people" who may be impacted by the crisis. For example, in the instance of the YikYak Threats, it was necessary for MU to provide emotional support for its stakeholders close to campus (students and perhaps faculty and staff), but not to alumni who lived across the country who were not personally threatened by the incident. However, it was appropriate for MU to give information to ease suffering after the event to both of these groups. At times, different stakeholder groups may even have conflicting needs, making it impossible for the organization to adequately respond to "people's needs after the event." A 
clarification in the wording of objectives to specify "people" as "priority stakeholders" or "intended audiences" may make this distinction clearer for those both using these objectives to plan crisis communication and to review past crisis communication.

\section{Defining Success}

To apply this scale effectively, the base crisis response must be considered from perspective of the audience receiving the messages, not necessarily the perspective of the organization responding to the crisis. For base crisis response to be successful, the messages must be received, understood, and acted upon by the intended audience. The perception of messages may differ between groups. For example, if an organization provides "information to ease suffering after the event," but it is not received or believed by the appropriate stakeholders, the organization has not fulfilled the objective. This was the case in the Bots crisis - MU provided information to contextualize what was happening to cause this crisis, but, because of weakened trust with MU and lack of understanding of the topic, many stakeholders did not believe MU's explanation. Alternatively, in the Graduate Student Working Conditions crisis, MU "gave information to protect people who could be harmed," but not all stakeholders received the information promptly, as it was shared via Chancellor Loftin's Twitter account and not all students utilize that platform. In these instances, the perspective of the practitioners planning these responses likely different from that of their intended audience.

Navigating success in the scale's objectives also becomes complex when stakeholder groups conflict in their expectations for what an appropriate response to the crisis should be. For example, in the Racism crisis, the information that would ease suffering following the crisis differed widely between stakeholder groups. Some groups wanted to hear from MU that the administration was in control of the situation, while others wanted MU to address changes that 
would be made on campus to address CS1950's demands. Similarly, success in these scale objectives becomes even more challenging when laws, policies or another authority prevent an organization from being able to meet stakeholders' expectations, as evidenced in the Planned Parenthood crisis. Ultimately, even though many stakeholders wanted MU to proceed differently, MU was required to follow state law.

\section{Final Discussion}

Building upon Coombs's research in Situational Crisis Communication Theory, Page's scale provides a tool for both practitioners and researchers to measure an organization's base crisis response. This chapter identifies several opportunities for strengthening the reliability of this scale in evaluating a wide variety of crises. As presented above, these suggestions include revisiting objectives to address speed of base crisis response, more specifically defining the term "people" in the objectives to add clarity, to consider a different set of objectives for crises where continuity information is more applicable than safety information, and to add clarity to the scale for rating objectives based on the intended audience's perspective.

This paper also heeds Coombs's call for researchers to further academic discourse around base crisis response. In measuring the base crisis response in a complex, real-life crisis, it was evident that it was not possible for MU to fully satisfy the scale's objectives in the eyes of all stakeholders, especially when the points of view of some key groups of stakeholders directly conflicted. The reality of such Catch-22s for organizations in crisis highlights the crucial importance of ongoing communication with key groups of stakeholders to build and maintain trust. Unfortunately, the issues that bubbled up at MU in fall 2015 are still present in society, nearly six years later. To continue to build trust with its stakeholders that will carry over into 
times of crisis, MU must ensure stakeholders feel their needs are being considered and addressed.

\section{Limitations and Future Research}

This study is only one example of applying Page's scale for measuring base crisis response and had several limitations. The timeline studied was limited for feasibility of the study, so adjusting information may have continued after the end of the studied time period. Specifically, this prevented inclusion of the Melissa Click crisis in this study. Additionally, not all of MU's communication pieces were able to be included in the analysis. Communication pieces not studied included communications from specific schools/colleges, meetings/calls/outreach to stakeholder groups, personal communications in return to outreach, not all emails and pieces of communication with broken links that could no longer be accessed.

Another limitation of this study is the point of view of the researcher. Although the researcher sought to assume the stakeholders' point of view as best as possible, the data could only be fully accurate if the stakeholders themselves responded to the scale. This study also does not compare MU's measured base crisis response with measured reputational outcomes to test the validity of the scale, as Page does in his original study. Quantitative reputational outcomes, like decreased student enrollment following the crisis, are known, but this study does not specifically measure stakeholders' perception of the organization's post-crisis reputation. Further research should be done to analyze the validity of Page's finding that $50 \%$ of an organization's reputational outcomes can be determined by its base crisis response.

In identifying considerations for Page's scale, this study opens the door for additional research to explore alternate scale objectives to measure base crisis response for crises 
warranting continuity information, as well as a system for determining which scale is appropriate for which type of crisis. 


\section{References}

Agle, B.R., Mitchell, R.K. and Sonnenfeld, J.A. (1999) 'Who matters to CEOs? An investigation of stakeholder attributes and salience, corporate performance, and CEO values', Academy of Management Journal, 42 (2), 507-525.

Allen, M. W., and Caillouet, R. H. (1994). Legitimate endeavors: Impression management strategies used by an organization in crisis, Communication Monographs, 61, 44-62.

Arpan, L. M., \& Pompper, D. (2003). Stormy weather: testing "stealing thunder" as a crisis communication strategy to improve communication flow between organizations and journalists. Public Relations Review, 29(3), 291. https://doiorg.proxy.mul.missouri.edu/10.1016/S0363-8111(03)00043-2

Barkley, K. (2020). Does one size fit all? The applicability of situational crisis communication theory in the Japanese context. Public Relations Review, 46(3), N.PAG. https://doiorg.proxy.mul.missouri.edu/10.1016/j.pubrev.2020.101911

Benoit, W. L. (1992). Union Carbide and the Bhopal tragedy. Paper presented at the annual meeting of the Speech Communication Association, Chicago

Benoit, W. L. (1995). Accounts, Excuses, and Apologies: A Theory of Image Restoration. Albany, NY: State University of New York Press

Benoit, W. L. (1997). Image repair discourse and crisis communication. Public Relations Review, 23(2), 177-186. doi:10.1016/s0363-8111(97)90023-0

Bryson, J.M. (2004) 'What to do when stakeholders matter: Stakeholder identification analysis techniques', Public Management Review, 6, 21-53.

Claeys, A.-S., Cauberghe, V., \& Vyncke, P. (2010). Restoring reputations in times of crisis: An experimental study of the Situational Crisis Communication Theory and the moderating 
effects of locus of control. Public Relations Review, 36(3), 256-262. https://doiorg.proxy.mul.missouri.edu/10.1016/j.pubrev.2010.05.004

Claeys, A.-S., \& Coombs, W. T. (2020). Organizational Crisis Communication: Suboptimal Crisis Response Selection Decisions and Behavioral Economics. Communication Theory (1050-3293), 30(3), 290-309. https://doi-org.proxy.mul.missouri.edu/10.1093/ct/qtz002

Coombs, W. T. (1995). Choosing the Right Words. Management Communication Quarterly, 8(4), 447-476. doi:10.1177/0893318995008004003

Coombs, W. T., and Holladay, S. J. (1996). Communication and attributions in a crisis: An experimental study of crisis communication, Journal of Public Relations Research, 8 , 279-295. Coombs, W. T., and Holladay, S. J. (2001). An extended examination of the crisis situation: A fusion of the relational management and symbolic approaches, Journal of Public Relations Research, 13, 321-340.

Coombs, W. T. (2006). The Protective Powers of Crisis Response Strategies: Managing Reputational Assets During a Crisis. Journal of Promotion Management, 12(3/4), 241260. https://doi-org.proxy.mul.missouri.edu/10.1300/J057v12n03_13

Coombs, W. T. (2007). Protecting organization reputations during a crisis: The development and application of situational crisis communication theory. Corporate Reputation Review, 10(3), 163-176. doi:10.1057/palgrave.crr.1550049

Coombs, W. T. (2016). Reflections on a meta-analysis: Crystallizing thinking about SCCT. Journal of Public Relations Research, 28(2), 120-122. https://doiorg.proxy.mul.missouri.edu/10.1080/1062726X.2016.1167479

Eligon, J., \& Pérez-Peña, R. (2015, November 9). University of Missouri Protests Spur a Day of Change. The New York Times. Retrieved from 
https://www.nytimes.com/2015/11/10/us/university-of-missouri-system-presidentresigns.html

Jeong, S.-H. (2009). Public's Responses to an oil spill accident: A test of the attribution theory and situational crisis communication theory. Public Relations Review, 35(3), 307-309. https://doi-org.proxy.mul.missouri.edu/10.1016/j.pubrev.2009.03.010

Kim, J. (2017). Elaborating the halo effect of SCCT: how and why performance history affects crisis responsibility and organizational reputation. Journal of Public Relations Research, 29(6), 277-294. https://doiorg.proxy.mul.missouri.edu/10.1080/1062726X.2017.1405812

Kim, S., \& Sung, K. (2014). Revisiting the Effectiveness of Base Crisis Response strategies in Comparison of Reputation Management Crisis Responses. Journal of Public Relations Research, 26(1), 62-78. https://doiorg.proxy.mul.missouri.edu/10.1080/1062726X.2013.795867

Missourian Staff. (2015, November 7). UPDATE: Protesters meet UM System president outside Kansas City fundraiser. Columbia Missourian. https://www.columbiamissourian.com/news/higher_education/wolfe-apologizes-foractions-during-protest-at-homecoming-parade/article_ecbd2628-84d2-11e5-89792f08eccf644a.html

Page, T. G. (2020). Measuring success: Explications and measurement scales of instructing information and adjusting information. Public Relations Review, 46(4), N.PAG. https://doi-org.proxy.mul.missouri.edu/10.1016/j.pubrev.2020.101952

Park, H. (2017). Exploring effective crisis response strategies. Public Relations Review, 43(1), 190-192. https://doi-org.proxy.mul.missouri.edu/10.1016/j.pubrev.2016.12.001 
Seeger, M. W., \& Ulmer, R. R. (2002). A Post-Crisis Discourse of Renewal: The Cases of Malden Mills and Cole Hardwoods. Journal of Applied Communication Research, 30(2), 126. https://doi-org.proxy.mul.missouri.edu/10.1080/00909880216578

Sellnow, T., Sellnow, D., Lane, D., \& Littlefield, R. (2012). The Value of Instructional Communication in Crisis Situations: Restoring Order to Chaos. Risk Analysis, 32: 633643. doi:10.1111/j.1539-6924.2011.01634.x

Sheth, A., Southard, S., \& Bates, C. (2005). Impact of Past Crises on Current Crisis Communication Insights from Situational Crisis Communication Theory. Technical Communication, 52(1), 101.

Sisco, H. F., Collins, E. L., \& Zoch, L. M. (2010). Through the looking glass: A decade of Red Cross crisis response and situational crisis communication theory. Public Relations Review, 36(1), 21-27. doi:10.1015/j.pubrev.2009.08.018

State Historical Society of Missouri. (2021, February 22). Lucile Bluford. State Historical Society of Missouri Historic Missourians. https://historicmissourians.shsmo.org/lucilebluford

Sturges, D. L. (1994). Communicating through Crisis: A Strategy for Organizational Survival. Management Communication Quarterly, 7(3), 297316. https://doi.org/10.1177/0893318994007003004

Wartick, S. (1992) 'The relationship between intense media exposure and change in corporate reputation', Business \& Society 31, 33-49.

Weick, K. E. (1988). Enacted sensemaking in crisis situations. Journal of Management Studies, 25(4), 305-317. doi:10.1111/j.1467-6486.1988.tb00039.x 
Williams, M. R. (2017, August 21). MU enrollment is down but last year's freshmen came back. The Kansas City Star. Retrieved from https://www.kansascity.com/article168519362.html

Williams, M. R. (2016, August 22). MU, expecting 3,000 fewer students, praises quality freshmen and high retention. The Kansas City Star. Retrieved from https:/www.kansascity.com/news/local/article97163147.html 


\section{Appendix A: Timeline}

Aug. 14 - Graduate students informed via email from vice chancellor for graduate studies Leona Rubin that MU would end its subsidized health insurance, due to an IRS interpretation of the Affordable Care Act, effective the following day.

Aug. 17 - Chancellor R. Bowen Loftin issues apology letter to grad students for the lack of appropriate notice for the change and creating a task force to investigate solutions for affordable health insurance for graduate students.

Aug. 18 - The Forum on Graduate Rights publishes a letter of demands, addressing graduate student issues beyond only health insurance. If the administration does not fulfil the demands by Aug. 25, the letter states, graduate students will stage a walkout on Aug. 26.

Aug. 21 - Chancellor Loftin announces that MU has reversed its decision and it will not revoke health insurance subsidies for graduate students after all. Graduate student groups reply on Twitter that, although MU had met their demand for health insurance, several items they had raised are still unaddressed.

MU GPC @Mizzou_GPC · Aug 21, 2015

$\checkmark$ Health insurance subsidy

$\square$ Living wage

$\square$ Fee waiver

$\square$ On-campus daycare

$\square$ On-campus housing

\#Mizzou @MUGradRights

-1) MU Grad Rights @MUGradRights.Aug 21, 2015

.@bowtieger @Mizzou Several items on the list of demands presented to administration still unaddressed. \#MizzouUnited \#Gradlnsurance

Q 1 七】 $40 \quad$ ○ $30 \quad \uparrow$

Aug. 22 - Graduate Professional Council publishes a letter to the MU community, saying the administration's plans to address their grievances aren't good enough and that the "shared governance" model that the university utilizes often puts student needs on the backburner. 
Aug. 24 - Representative Kurt Schaefer threatens to withhold money from MU because Planned Parenthood doctor has privileges at MU's University Hospital.

Aug. 26 - Graduate students hold rally. Some professors cancel classes in support of the rally, with some professors planning to attend the rally.

Aug. 27 - At faculty council meeting, Leona Rubin apologies for her handling of the situation, explaining that she had received guidance from professional organizations that turned out to be incorrect and mentioning poor communication among the MU administration.

Sept. 8 - With frustration continuing to mount among graduate students and some sympathetic faculty, MU holds graduate student forum, where leadership responds to concerns of graduate students.

Sept. 12 - Missouri Students Association President Payton Head posts viral Facebook post detailing incident he experienced near MU campus, with men in a pickup truck yelling racial slurs at him. The post also comments on campus incidents that other students have experienced related to their identity. The impassioned post calling on Mizzou to "wake up" is shared thousands of times on Facebook, in addition to receiving coverage in national outlets including the St. Louis Post Dispatch and Washington Post.

Sept. 15 - MU ends 26-year relationship between MU's medical and nursing schools and Planned Parenthood.

Sept. 17 - Five days after Head's Facebook post, Chancellor Loftin makes statement referencing recent incidents, calling on the MU community to stand against incidents of bias and discrimination. 
At faculty council meeting, members question Chancellor Loftin about the reasons of the recent departure of School of Medicine dean and voice concern with elimination of tuition waivers for some graduate assistantships.

Sept. 21 - MU Law professor Royce de R. Barondes files lawsuit against UM Curators and UM President Tim Wolfe, saying that MU's policy banning concealed weapons on campus infringes upon his constitutional rights and fails to follow a gun regulation law recently passed by Missouri voters in August 2016. Report shows prevalence of sexual assault at MU is higher than average among peer institutions. Faculty and students continue to speak out publicly about the campus climate, Planned Parenthood and graduate school issues.

Sept. 24 - Nearly 100 students gather for "Racism Lives Here" rally on MU campus. The group is unsatisfied with the length of time it took Chancellor Loftin to respond to Head's Facebook post and said his statement did not show the administration was doing anything to help its black students. Graduate student Danielle Walker opens the rally, saying through a megaphone, "The University of Missouri does not care about black students. Racism lives here. Not in Ferguson. Not in Baltimore. Not in South Carolina. Right here.”

Sept. 24 - MU Health Care announced that it will discontinue its "refer-and-follow" privileges on Dec. 1, meaning the only doctor in Columbia performing abortions loses will lose such privileges at MU's University Hospital and, by state law, that the doctor can no longer perform abortions in Columbia.

Sept. 30 - The Forum on Graduate Rights' organizing committee, renamed the Coalition of Graduate Workers, announces plans to unionize by the end of 2015 or early 2016. 
Oct. 1 - Around 40 students hold Racism Lives Here rally in MU Student Center. Participants chant, "White silence is violence. No justice, no peace." Student participants shout that they feel they do not belong, that they are not respected, that they do not have space on campus and that faculty does not have the necessary difficult conversations around race.

"We want to see a hate crime policy initiated. We want our chancellor to formally make an announcement that we do have a racial problem here on campus and that they are seeking to make sure it gets addressed properly," said participant Danielle Walker.

Rally participants say they plan to continue to protest until MU administration responds to their demands.

Oct. 4 - Intoxicated student disrupts Legion of Black Collegians (LBC) Homecoming performance rehearsal, using a racial slur. LBC details the incident in a letter shared on Twitter, with criticism of the speed of the reaction of the MU safety officer at the scene.

Oct. 5 - Chancellor Loftin posts a video message. "It's happened again. Just last night, on Traditions Plaza. Hate and racism were alive and well at Mizzou," he says in the video. "It's enough. Let's stop this. Let's end hatred and racism at Mizzou. We're part of the same family. You don't hate your family."

Oct. 6 - Students participate in a Black Lives Matter study-in in Jesse Hall on MU Campus. Student identified as the perpetrator of the Oct. 4 incident removed from campus while a conduct process is completed.

Oct. 7 - Students protest the Thomas Jefferson statue on the Quad by placing sticky notes on the statue with words like "racist," "rapist," "slave-owner," and "misogynist." A student petition to remove the statue began to circulate in August. 
Oct. 8 - Chancellor Loftin announces required diversity and inclusion training to be implemented for students, faculty and staff.

Islamic flag burned on the Quad during Young Americans for Liberty event with approximately 200 attendees protesting ISIS.

At faculty council meeting, faculty members voice frustration about lack of communication from university leadership and lack of input from faculty on a variety of issues, including graduate student issues and Planned Parenthood.

Oct. 9 - Original epitaph of Thomas Jefferson's grave rededicated by donor group, Jefferson Club Board of Trustees, the same group that funded the statue on the Quad. The epitaph was originally donated to the university by the Jefferson family in 1885 . It was sent to the Smithsonian Institution for restoration in 2012 and was returned last year, but could not be displayed at that time due to ongoing construction. Chancellor Loftin speaks at the dedication ceremony.

Oct. 10 - Student group Concerned Student 1950 (CS 1950) blocks UM System President Tim Wolfe's car in MU Homecoming parade. Protestors frustrated that Wolfe did not get out of his car to speak with them and say that his car knowingly bumped one of the protestors.

Oct. 14 - Chancellor Loftin guarantees graduate student health insurance subsidies will continue now and in the future.

Oct. 15 - Still frustrated with the conditions of their treatment as employees, graduate students hold grade-in in Jesse Hall, in conjunction with graduate student unions across the country. Oct. 16 - Graduate student Jonathan Butler publishes letter to Chancellor Loftin praising recent announcement of required diversity and inclusion training, but states that it is not enough. 
Oct. 20 - Students hold counter sticky note protest and organize counter petition in support of Thomas Jefferson statue on the Quad.

Oct. 20 - MU Nursing School announces it will enter into new agreements with Planned Parenthood to allow some students to complete clinical rotations there.

Oct. 21 - Korean Student Association meets with owner of campus restaurant Sunshine Sushi, as they believe the logo resembles the flag of Imperial Japan and is insensitive to customers from South Korea and other Asian countries subjugated by Japan during World War II.

Oct. 21 - CS 1950 issues list of eight demands, including:

- A news conference of Wolfe reading a handwritten, formal apology.

- The immediate removal of Wolfe as UM System President.

- Enforcement of mandatory racial awareness and inclusion curriculum for all faculty, staff and students, controlled by a board of color.

- An increase in the percentage of black faculty and staff to 10 percent by the 2017-18 academic year, and the development by May 1 of a 10-year plan to promote a safer, more inclusive campus.

- An increase in funding to hire more mental health professionals for the MU Counseling Center, particularly those of color, and more staff for the social justice centers on campus.

The group requested a response from the administration by Oct. 28 .

Oct. 24 - A swastika drawn in human feces is found on a MU residence hall bathroom wall. 
Oct. 26 - Members of CS 1950 meet with Tim Wolfe but say talks did not achieve resolution. The students said Wolfe acknowledged care for black students, but that he was not fully aware of systemic racism on campus and did not mention any plans for fulfilling CS 1950's demands.

Oct. 29 - MU Health Care workers protest outside Tim Wolfe's office during meeting where removal of merit pay for union workers is discussed.

Nov. 2 - Graduate student Jonathan Butler stages hunger strike in protest of Tim Wolfe, to end only when Wolfe resigns as UM System President.

CS 1950 begins to camp out in protest on MU's Carnahan Quad in support of Jonathan Butler, saying they will not leave until Wolfe leaves MU.

Nov. 3 - Wolfe meets with CS 1950 members. Students take issue with the fact that he did not react when they protested in front of his car in the Homecoming parade and accuse him of not caring about racism.

Students deliver to Chancellor Loftin a petition with more than 2,500 signatures in support of Planned Parenthood.

CS 1950 announces they plan to stop spending money at MU until Tim Wolfe resigns. Nov. 4 - MU English Department votes no confidence in Chancellor Loftin's leadership. CS 1950 holds a press conference on MU's Traditions Plaza, calling for the removal of Tim Wolfe.

Nov. 5 - Reversing a June decision that reduced the amount of tuition waivers to be received by some graduate assistants, full tuition waivers will be extended to all graduate student assistantships for the coming year. 
Faculty Council expresses deep concern with communications within the university and growing uncertainty about the university's leadership.

In conjunction with its boycott, CS 1950 holds protest, demonstrating throughout campus buildings.

Nov. 6 - Wolfe issues public apology for his inaction when stopped by protesters in the Homecoming parade.

Chancellor Loftin issues statement regarding safety of Jewish students at MU, following swastika incident.

Student protestors confront Wolfe in Kansas City when he is exiting a fundraising event. While filming the interaction, students ask Wolfe to define "systemic oppression" and Wolfe fumbles. The video is posted on social media and goes viral.

Nov. 7 - CS 1950 protests throughout campus during visit day for potential students.

Black Mizzou football players announce they plan to boycott all football activities until Wolfe is removed.

Nov. 8 - Missouri Governor Jay Nixon makes statement saying racism has no place at MU. Mizzou head football coach Gary Pinkel posts tweet in support for Black players, saying the entire team is behind the boycott.

Tim Wolfe issues a statement thanking those sharing their concerns and expressing that MU leadership is open to continuing this dialogue. The letter explains that several of the issues raised in CS 1950's demands are already planned to be addressed in a forthcoming plan approved in summer 2015 that is to be put forward in April 2016. 
Students express dissatisfaction with the statement, with graduate student organizations threatening another two-day walkout. The statement "doubled-down on business as usual as the path forward for our troubled campus," they said.

Students continue to camp on Quad in protest. Chancellor Loftin visits the site, speaking with students and providing propane heaters.

At the state and national level, Missouri lawmakers of both parties call for Wolfe to step down. Faculty plan a walk-out from class on Monday, Nov. 9, and a teach-in on Tuesday, Nov. 10, in support of student activists.

Nov. 9 - 738 Black alumni sign letter calling for improved race relations on campus, including a call for the Mizzou Alumni Association to start a black alumni chapter.

At a morning emergency UM System Board of Curators meeting, Wolfe announces his resignation.

After Wolfe's resignation, football team announces it is ready to play. Nine deans sign letter calling for Chancellor Loftin's dismissal, citing failed leadership examples of graduate student health insurance, elimination of the Vice Chancellor for Health Science position, removal of the medical school dean and "creating a toxic environment through threat, fear and intimidation."

Nearly seven hours after Wolfe's resignation, Chancellor Loftin announces his resignation, effective at the end of the year.

During celebrations after Wolfe's resignation, communications professor Melissa Click asks for "muscle" to remove journalist Mark Schierbecker, declaring circle formed by protestors a safe space where media is barred. Assistant director for Greek Life Janna Bassler confronts student photojournalist on assignment for ESPN Tim Tai, also urging him to leave. Tai stands his 
ground, explaining that the Quad where the group is gathered is a public space and the First Amendment protects the rights of the group and the journalists to be there.

Nov. 10 - Chuck Henson is named interim vice chancellor for inclusion, diversity and equity, after UM Curators established the position the day prior.

Form on Graduate Rights rallies on Traditions Plaza, collecting signatures to form a union.

First amendment attorneys, including communications law professor Sandy Davidson, take issue with MUPD's statement asking students to report "hateful and/or hurtful speech," saying it limits First Amendment rights at MU.

Protestors camping on Quad begin to disassemble their camp and leave.

Shortly after 6 p.m., threatening posts appeared on the anonymous social media platform, YikYak: "Some of you are alright. Don't come to campus tomorrow. I'm going to stand my ground tomorrow and shoot every black person I see."

MSA President Payton Head posts on Facebook that the Ku Klux Klan was "confirmed" to be in Columbia, later retracting his post.

On social media, students advise each other to remain indoors. Many students stay in their campus housing, and some students leave campus. Army ROTC is instructed to dress in plain clothes the next day.

Nov. 11 - At 1:50 a.m., MU Police arrested Hunter Park, a 19-year-old Missouri University of Science and Technology student, with charges of making a terroristic threat. At 5:07 a.m., MU's alert system tweeted that the suspect had been arrested.

In response to campus threat the night before, some downtown business close, some classes are canceled, and some organizations call off meetings. 
Title IX complaints filed against Janna Basler and Melissa Click by former Journalism School associate dean Brian Brooks. Basler is put on leave.

Nov. 12 - Mike Middleton, first Black student admitted to MU Law School and co-founder of Legion of Black Collegians, named interim UM System President.

College students around the country demonstrate support for MU.

Nov. 13 - CS 1950 holds "We will not be afraid" march throughout campus.

Head football coach Gary Pinkel resigns because of health reasons.

Nov. 15 - Faculty members organize Peace and Inclusivity Parade in Columbia after unrest.

Nov. 18 - Students vote down proposed library fee.

Nov. 19 - UM Curator Ann Covington resigns for personal reasons.

Ben Shapiro speaks on MU campus, hosted by College Republicans, speaking out against political correctness. Conservative students at the event say their voice is diminished on campus. Nov. 20 - UM Curators hold listening session with students.

Nov. 23 - Mizzou Alumni Association forms Black Alumni Network.

Nov. 24 - Columbia Planned Parenthood is no longer offering abortions.

Nov. 30 - MU will not extend Planned Parenthood doctor's privileges. Judge blocks revocation of Columbia clinic's abortion license.

Planned Parenthood supporters hold rally to ask MU to reconsider decision that led to the end of abortion services in Columbia.

Dec. 2 - MU creates Office for Civil Rights and Title IX.

Dec. 4 - Interim Chancellor Hank Foley reinstates MU Health Care organizational system that former Chancellor Loftin had abolished. 
Dec. 7 - Task Force on Graduate Student Health makes 3 recommendations:

- Provide a financial fellowship to graduate student employees

- Increase graduate student stipends

- Provide a "silver" level insurance plan option to graduate student employees

Muslim student files lawsuit against professor for allegedly making racist comments to her that eventually caused her grade in the course to suffer.

Dec. 11 - UM Curators announce steps to heal racial tensions and promote inclusivity.

Dec. 12 - Another student, this time an MU student, arrested for making a terroristic threat on YikYak.

Dec. 16 - Janna Basler is reinstated at the Office of Greek Life.

Dec. 17 - Fulfilling two of the eight initiatives the UM Curators announced as steps forward in November, System appoints MU Law professor David Mitchel as chair of newly created UM System Diversity, Equity and Inclusion Task Force.

Dec. 28 - Federal judge rules Columbia Planned Parenthood to keep license to perform abortions. 